\title{
Recovery Plan for Scots Pine Blister Rust Caused by Cronartium pini
}

Mee-Sook Kim, ${ }^{1,+}{ }^{+}$Jarkko Hantula, ${ }^{2}$ Juha Kaitera, ${ }^{3}$ Paul J. Zambino, ${ }^{4}$ Stephen Woodward, ${ }^{5}$ Bryce A. Richardson, ${ }^{6}$ Jane E. Stewart, ${ }^{7}$ Pauline Spaine, ${ }^{8}$ David C. Shaw, ${ }^{9}$ Yu Takeuchi, ${ }^{10}$ and Ned B. Klopfenstein ${ }^{6}$

${ }^{1}$ USDA Forest Service, Pacific Northwest Research Station, Corvallis, OR 97331, U.S.A.

${ }^{2}$ Natural Resources Institute Finland, Latokartanonkaari 9, Fl-00790 Helsinki, Finland

${ }^{3}$ Natural Resources Institute Finland, Paavo Havaksen tie 3, FI-90570 Oulu, Finland

${ }^{4}$ USDA Forest Service, Forest Health Protection, Coeur d'Alene, ID 83815, U.S.A.

${ }^{5}$ University of Aberdeen, School of Biological Sciences, Aberdeen, Scotland, U.K.

${ }^{6}$ USDA Forest Service, Rocky Mountain Research Station, Moscow, ID 83843, U.S.A.

${ }^{7}$ Colorado State University, Department of Agricultural Biology, Fort Collins, CO 80525, U.S.A.

${ }^{8}$ USDA APHIS, PPQ-PHP-IRM, Plants for Planting Policy, Riverdale, MD 20737, U.S.A.

${ }^{9}$ Oregon State University, Department of Forest Engineering, Resources and Management, Corvallis, OR 97331, U.S.A.

${ }^{10}$ North Carolina State University, Center for Integrated Pest Management, Raleigh, NC 27606, U.S.A.

Accepted for publication 11 September 2021.

${ }^{\dagger}$ Corresponding author: meesook.kim@usda.gov 
Table of Contents

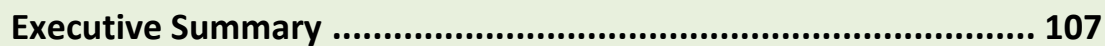

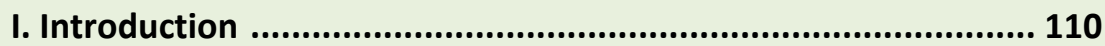

II. Biology and Symptoms ........................................................... 112

III. Spread and Climate-Host Suitability Map ................................ 114

IV. Monitoring, Detection, and Identification ............................. 116

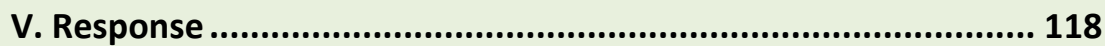

VI. USDA Pathogens Permits and Regulatory Issues .................... 119

VII. Economic Impact and Compensation ................................... 119

VIII. Mitigation and Disease Management ................................ 120

IX. Research, Extension, and Education Priorities ......................... 123

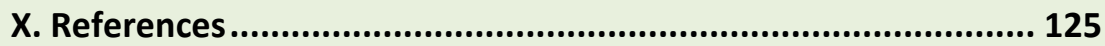

XI. Infrastructure and Experts ................................................... 128

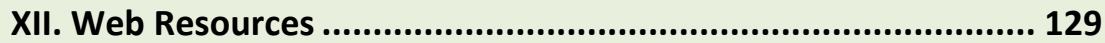

Keywords: Pinus sylvestris, Cronartium flaccidum, Peridermium pini, Endocronartium pini

Funding: We acknowledge the funding and support from the National Plant Disease Recovery System (NPDRS) of the USDA-Agricultural Research Service. In addition, this work was partially funded by the USDA Forest Service, Forest Health Protection, Special Technology Development Program (R1-FY2020-01). The findings and conclusions in this publication are those of the authors and should not be construed to represent any official USDA or U.S. Government determination or policy. 
This recovery plan is one of several plant disease-specific documents produced as part of the National Plant Disease Recovery System (NPDRS) requested by the Homeland Security Presidential Directive Number 9 (HSPD-9). The purpose of the NPDRS is to ensure that the tools, infrastructure, communication networks, and capacity required for mitigating impacts of high-consequence plant disease outbreaks are implemented so that a reasonable level of crop production is maintained.

Each plant disease-specific plan is intended to provide a brief summary of the disease, assess the status of critical recovery components, and identify disease management research, extension, and education needs. These documents are not intended to serve as stand-alone documents that address all of the many and varied aspects of plant disease outbreaks, all of the critical decisions that must be determined, or all of the actions needed to achieve effective response and recovery. These plans are, however, documents that will help the USDA to guide further efforts directed toward plant disease recovery.

\section{Executive Summary}

Scots pine blister rust caused by Cronartium pini, which includes the fungal rust pathogen with either a heteroecious life cycle (previously known as Cronartium flaccidum) or an autoecious life cycle (formerly known as Peridermium pini or Endocronartium pini), is capable of infecting many Eurasian pines including Pinus sylvestris (Scots pine), P. pinaster (maritime pine), P. pinea (Italian stone pine), P. halepensis (Aleppo pine), P. mugo (mugo pine), P. nigra (Austrian pine or black pine), P. brutia (brutia pine or Turkish pine), $P$. densiflora (Japanese red pine or Korean red pine), $P$. radiata (Monterey pine or radiata pine), P. koraiensis (Korean pine), P. massoniana (Masson pine), P. tabuliformis (Manchurian red pine), P. taiwanensis (Taiwan red pine), P. pumila (Siberian dwarf pine), P. uncinata (Swiss mountain pine), P. wallichiana (Himalayan pine or Bhutan pine), P. takahasii, and P. yunnanensis (Yunnan pine) (Table 1). According to population genetic studies, the two forms of $C$. pini have not been differentiated by presently available DNA sequencing analyses, likely because gene flow occurs between the two forms. However, the aecia of the two forms of the rust pathogen differ in the heterozygotic state, which can only be observed in the

\begin{tabular}{|c|c|c|}
\hline \multicolumn{3}{|c|}{$\begin{array}{c}\text { TABLE } 1 \\
\text { Pine aecial hosts of Cronartium pini }\end{array}$} \\
\hline Host $^{a}$ & Geographic region & Reference \\
\hline Pinus sylvestris (Scots pine) & Temperate and other regions & Kaitera and Hantula 1998 \\
\hline P. pinea (Italian stone pine) & Mediterranean region & CABI 2020 \\
\hline P. mugo (mountain pine) & Alps and to south and east & Kaitera and Nuorteva 2008 \\
\hline P. nigra (Austrian pine) & Mediterranean region & CABI 2020 \\
\hline $\begin{array}{l}\text { P. nigra subsp. laricio (Laricio pine) } \\
\text { (syn. } P \text {. nigricans; } P \text {. austriaca) }\end{array}$ & Mediterranean region & \\
\hline$P$. pinaster (maritime pine) & Mediterranean and other regions & CABI 2020 \\
\hline P. halepensis (Aleppo pine) & Mediterranean region & Moricca and Ragazzi 1996 \\
\hline P. densiflora (Japanese red pine or Korean red pine) & Japan & CABI 2020 \\
\hline P. brutia (brutia pine or Turkish pine) & Turkey & CABI 2020 \\
\hline P. koraiensis (Korean pine) & & CABI 2020 \\
\hline P. massoniana (Masson pine) & China & Yao and Peixin 1991 \\
\hline P. pumila (Siberian dwarf pine) & & CABI 2020 \\
\hline P. radiata (Monterey pine or radiata pine) & & CABI 2020 \\
\hline P. ponderosa (ponderosa pine) & & Gibbs and Kaitera 2018 \\
\hline P. tabuliformis (Manchurian red pine) & China & Yao and Peixin 1991 \\
\hline P. taiwanensis (Taiwan red pine) & & CABI 2020 \\
\hline P. takahasii & & CABI 2020 \\
\hline P. uncinata (Swiss mountain pine) & & CABI 2020 \\
\hline P. wallichiana (Himalayan pine or Bhutan pine) & & CABI 2020 \\
\hline P. yunnanensis (Yunnan pine) & & CABI 2020 \\
\hline
\end{tabular}


heteroecious form. The heteroecious form completes its life cycle alternating between pines and various species of flowering plants (Angiospermae) (see Table 2 for a list of alternate host species); the related autoecious form spreads directly from pine to pine. Scots pine blister rust is widely distributed across Eurasia. The impact is most severe on Scots pine and several Mediterranean pines.

Susceptibility of native North American pine species and populations to Scots pine blister rust is mostly unknown at this time, although $P$. radiata and $P$. ponderosa (ponderosa pine) are reported to be susceptible. $P$. resinosa (red pine), which is closely related to known hosts, should also be considered as a potential pine host. However, if the Scots pine blister rust pathogen possesses or gains the capacity to infect North American pines, the economic and ecological impacts could be quite significant, and the potential influences of climate change and other environmental factors remain

\begin{tabular}{|c|c|c|c|}
\hline \multicolumn{4}{|c|}{$\begin{array}{c}\text { TABLE } 2 \\
\text { Angiosperm telial (alternate) hosts of Cronartium pini }\end{array}$} \\
\hline Host & Reference & Host & Reference \\
\hline \multirow[t]{2}{*}{ Melampyrum sylvaticum } & \multirow{2}{*}{$\begin{array}{l}\text { Kaitera and Hantula 1998; } \\
\text { Kaitera et al. 1999, 2012; } \\
\text { Kaitera 1999; Kaitera and } \\
\text { Hiltunen } 2011\end{array}$} & Tropaeolum majus & $\begin{array}{l}\text { Kaitera and Hiltunen 2012; } \\
\text { Kaitera et al. 2012, 2015, } \\
\text { 2017a }\end{array}$ \\
\hline & & Veronica longifolia & $\begin{array}{l}\text { Kaitera and Hiltunen 2012; } \\
\text { Kaitera et al. 2012, 2015 }\end{array}$ \\
\hline Melampyrum pratense & $\begin{array}{l}\text { Kaitera 1999; Kaitera et al. } \\
2012\end{array}$ & Veronica incana & Kaitera et al. 2015 \\
\hline Melampyrum nemorosum & Kaitera and Nuorteva 2003a & Veronica daurica & $\begin{array}{l}\text { Kaitera et al. 2012, 2015, } \\
\text { 2017a }\end{array}$ \\
\hline Melampyrum arvense & Kaitera and Nuorteva 2003b & Veronica grandis & Kaitera et al. 2015 \\
\hline $\begin{array}{l}\text { Pedicularis palustris ssp. } \\
\text { palustris }\end{array}$ & $\begin{array}{l}\text { Kaitera et al. 1999, 2012; } \\
\quad \text { Kaitera and Hiltunen } 2011\end{array}$ & Veronica krylovii & Kaitera et al. 2015 \\
\hline Pedicularis sceptrum-carolinum & $\begin{array}{l}\text { Kaitera and Hiltunen 2012; } \\
\text { Kaitera et al. 2012, 2015 }\end{array}$ & Apocynum cannabinum & Kaitera et al. 2015 \\
\hline Pedicularis dolichorrhiza & Kaitera et al. 2012 & Asclepias incarnata & Kaitera and Hiltunen 2012 \\
\hline Pedicularis lapponica & Kaitera and Hiltunen 2011 & Bartsia alpina & $\begin{array}{l}\text { Kaitera and Hiltunen 2012; } \\
\text { Kaitera et al. 2012, 2017a }\end{array}$ \\
\hline Pedicularis groenlandica & Kaitera et al. 2015 & Caiophora lateritia & Kaitera et al. 2012 \\
\hline Verbena $\times$ hybrida & Kaitera and Hiltunen 2012 & Castilleja miniata & Kaitera et al. 2015 \\
\hline Verbena canadensis & Kaitera et al. 2012 & Delphinium elatum & \\
\hline Verbena officinalis & Kaitera and Hiltunen 2012 & Euphrasia stricta & $\begin{array}{l}\text { Kaitera and Hiltunen 2012; } \\
\text { Kaitera et al. 2012, 2015, } \\
\text { 2017a, 2018 }\end{array}$ \\
\hline Vincetoxicum hirundinaria & $\begin{array}{l}\text { Kaitera et al. 1999, 2012, } \\
\text { 2015, 2017a; Kaitera and } \\
\text { Hiltunen 2011, 2012 }\end{array}$ & Euphrasia breivipila & Kaitera et al. 2015 \\
\hline Vincetoxicum mongolicum & Kaitera et al. 1999 & Euphrasia officinalis & Kaitera et al. 2015 \\
\hline Vincetoxicum fuscum & Kaitera et al. 1999 & Euphrasia minima & Kaitera et al. 2015 \\
\hline Vincetoxicum nigrum & Kaitera et al. 1999 & Euphrasia nemorosa & Kaitera et al. $2017 \mathrm{c}$ \\
\hline Paeonia lactiflora & Kaitera et al. 2012, 2018 & Euphrasia frigida & Kaitera et al. $2017 \mathrm{c}$ \\
\hline Paeonia anomala & $\begin{array}{l}\text { Kaitera et al. 1999, 2012; } \\
\quad \text { Kaitera and Hiltunen } 2012\end{array}$ & Gentiana verna & \\
\hline Paeonia obovata & Kaitera et al. 2012 & Hyoscyamus niger & Kaitera et al. 2015 \\
\hline Paeonia officinalis & Kaitera et al. 1999, 2015 & Myrica gale & Kaitera et al. 2012, 2015 \\
\hline Paeonia tenuifolia & Kaitera et al. 2015 & Nicotiana rustica & Kaitera et al. 2015 \\
\hline Paeonia mlokosewitchii & Kaitera et al. $2017 \mathrm{~b}$ & Odontites verna & Kaitera et al. 2018 \\
\hline Paeonia oreogeton & Kaitera et al. $2017 \mathrm{~b}$ & Papaver rhoeas & Kaitera et al. 2018 \\
\hline Grammatocarpus volubilis & & Rhinanthus minor & Kaitera et al. 2015 \\
\hline Impatiens glandulifera & $\begin{array}{l}\text { Kaitera and Hiltunen 2012; } \\
\text { Kaitera et al. } 2015\end{array}$ & Rhinanthus aestivalis & Kaitera et al. 2015 \\
\hline Impatiens balsamina & Kaitera et al. 2012, 2015 & Rhinanthus serotinus & Kaitera et al. 2018 \\
\hline Impatiens parviflora & Kaitera et al. 2018 & Ruellia elegans & \\
\hline Loasa (Nasa) tricolor & Kaitera et al. 2012, 2015 & Saxifraga hostii & Kaitera et al. 2012, 2015 \\
\hline Loasa (Nasa) triphylla & $\begin{array}{l}\text { Kaitera and Hiltunen 2012; } \\
\quad \text { Kaitera et al. 2012, 2017a }\end{array}$ & Saxiraga cespitosa & Kaitera et al. 2012 \\
\hline Loasa (Nasa) urens & Kaitera et al. 2017a & Saxifraga exarata & Kaitera et al. 2012 \\
\hline Nemesia versicolor & Kaitera and Hiltunen 2012 & Schizanthus grahamii & \\
\hline Nemesia strumosa & Kaitera and Hiltunen 2012 & Siphonostegia chinensis & Yao and Peixin 1991 \\
\hline Nemesia floribunda & Kaitera et al. $2017 \mathrm{a}$ & Swertia fedtchenkoana & Kaitera et al. 2012, 2015 \\
\hline
\end{tabular}


unknown. The direct cost to control white pine blister rust (caused by C. ribicola) since its introduction into North America during the early 1900s has been estimated at over $\$ 1$ billion in current U.S. dollars, and this disease has caused much greater indirect losses through reduced forest productivity and ecological impacts.

Scots pine is one of the most widely distributed conifers in the world. It grows naturally from Scotland east to the Pacific Ocean, from the 69th latitude in Scandinavia to the Mediterranean Basin. In addition, Scots pine has been widely planted in colder regions of North America, and it has become naturalized in the northeastern and midwestern United States. It is planted in North America for erosion control, ornamental purposes, and pulp/timber production, but its primary economic value is as a Christmas tree crop. According to the 2019 Census of Horticultural Specialties in the United States (USDA-NASS 2019), nearly 2,857 operations sold 11.7 million Christmas trees valued at \$357.1 million in 2019, and Scots pine is one of the most commonly used Christmas tree species in the United States.

Scots pine blister rust is also called resin-top disease and top-dieback of pine for affected trees in all age and size classes. Symptoms in pine include stem swelling, branch flagging, excessive pitch flow, and top-kill, and, in the alternate hosts, leaf spotting. The rust pathogen is spread in nature by wind-borne spores, which require live hosts for infection. However, the rust pathogen can also be transported on infected plant materials that can be nonsymptomatic. Early infections of host plants by C. pini are difficult to detect and diagnose, but molecular techniques offer a potential approach for early detection and diagnosis.

Scots pine blister rust is widespread across Eurasia, and it has long been a major factor in reducing forest productivity in Europe; however, this rust disease has not been found in North America. The safest plant protection policy for North America would be to prohibit the importation of pine and nonpine hosts of Scots pine blister rust. If host plants were imported, a thorough visual inspection for signs and symptoms of Scots pine blister rust should be conducted, followed by a quarantine and/or extended monitoring. Early detection of Scots pine blister rust at port facilities can provide some defense against introduction. However, nonsymptomatic infections in this slow-developing disease could easily be overlooked by visual inspections, so out-plantings should be monitored for several years. Further diagnostic techniques, such as microscopy and simple DNA-based tools, can be used to confirm rust pathogen infection and identity in symptomatic plants. The following strategies may help to prevent the introduction of the Scots pine blister rust pathogen:

- Ban importation of living Scots pine trees/seedlings for nursery trade (Pinus spp. from all countries except Canada, Japan, and South Korea are currently prohibited from importation into the United States); allow importation of known angiosperm alternate hosts only as seed (or at least as dormant and leafless plants).

- Determine potential susceptibility of North American pines to Scots pine blister rust.

- Establish a monitoring system for Scots pine blister rust and other invasive rust pathogen species, especially in tree nursery and Christmas tree farm settings near likely points of introduction.

- Develop time-efficient, species-specific molecular tools to detect and identify C. pini.

- Develop models that predict potential spread of the Scots pine blister rust pathogen from introduction points using distribution of suitable hosts and bioclimatic models that identify suitable climate niches across the geographic ranges of diverse hosts.

- Improve educational awareness about potentially invasive rust pathogens among plant diagnosticians, extension agents, forest managers, nursery growers, Christmas tree growers, horticulturalists, and the general public. 
- Conduct genetic analyses of the Scots pine blister rust pathogen and its known and potential hosts to predict potential invasive risks in North America.

\section{Introduction}

The causal agent of Scots pine blister rust (resin-top disease; top-dieback of pine) is Cronartium pini (Willd.) Jørstad (syn. Cronartium flaccidum [Alb. \& Schwein.] G. Winter, Peridermium pini [Pers.] Lév., C. asclepiadeum [Willd.] Fr., Endocronartium pini [Pers.] Y. Hiratsuka) (Fig. 1). The sexually reproducing heteroecious form of the Scots pine blister rust pathogen, formerly known as C. flaccidum, completes its life cycle by alternating between pines mostly in the subgenus Pinus (hard pines) and flowering plants of various families. Scots pine blister rust is also caused by an autoecious form of the rust pathogen, formerly known as Peridermium pini and Endocronartium pini, that spreads directly from pine to pine.

Scots pine blister rust affects many Pinus species in Europe and Asia. The heteroecious form causes severe damage in natural forests on P. sylvestris L. (Scots pine) in northern Europe, whereas the heteroecious form of $C$. pini is reported on Scots pine, P. pinaster Ait. (maritime pine), P. pinea L. (Italian stone pine), P. halepensis Mill. (Aleppo pine), P. mugo Turra (mugo pine), and P. nigra Arn. (Austrian pine or black pine) in southern Europe. Other reported Pinus host species of $C$. pini include P. brutia Ten. (brutia pine or Turkish pine), P. densiflora Siebold \& Zucc. (Japanese red pine or Korean red pine), P. radiata D.Don (Monterey pine or radiata pine), P. koraiensis Siebold \& Zucc. (Korean pine), P. massoniana Lamb. (Masson pine), P. tabuliformis Carrière (Manchurian red pine), P. taiwanensis Hayata (Taiwan red pine), P. pumila Regel (Siberian dwarf pine), P. uncinata Ramond ex DC. (Swiss mountain pine), P. wallichiana A.B.Jacks. (Himalayan pine or Bhutan Pine), P. takahasii Nakai, and P. yunnanensis Franch. (Yunnan pine) (CABI 2020). North American pines reported to be susceptible to C. pini include $P$. radiata (CABI 2020) and

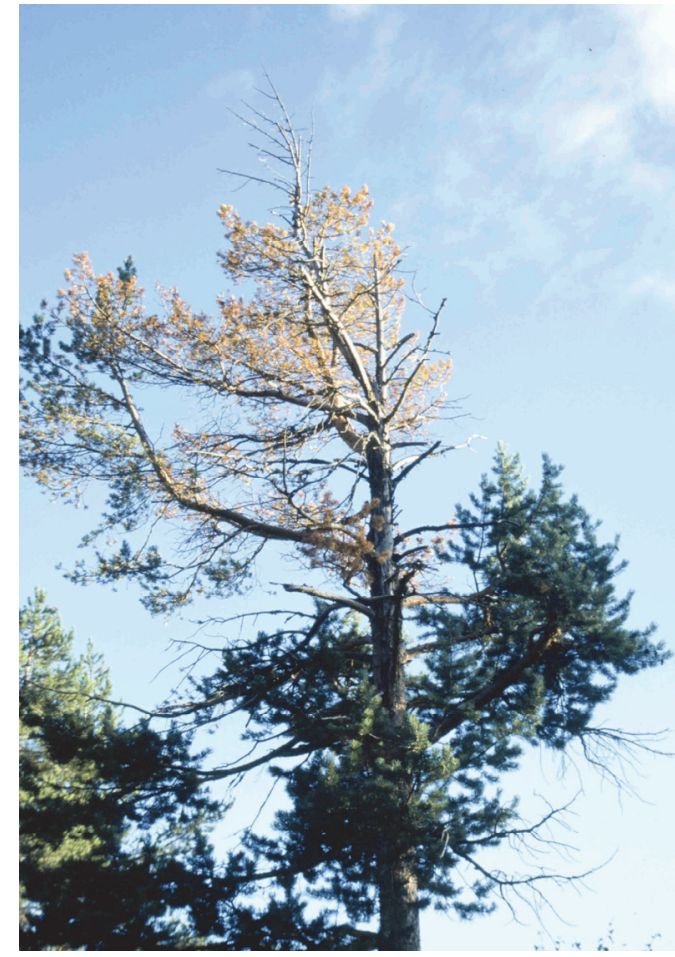

FIGURE 1

Scots pine blister rust (resin-top disease) caused by Cronartium pini on Scots pine (Pinus sylvestris). (Photo by Juha Kaitera.) P. ponderosa Douglas ex C.Lawson (ponderosa pine) (Gibbs and Kaitera 2018). The autoecious form of $C$. pini causes damage on Scots pine and mugo pine (Kaitera and Nuorteva 2008). Of the Eurasian pine hosts, Scots pine and Austrian/black pine are commonly planted in North America. Needle symptoms have been reported after artificial or natural exposure to $C$. pini inoculum on other native and exotic two-needle pines that occur in the United States (Raddi and Fagnani 1978). The alternate (telial) hosts for the heteroecious form of C. pini belong to the angiosperm families: Gentianaceae, Balsaminaceae, Loasaceae, Paeoniaceae, Tropaeolaceae, Verbenaceae, Apocynaceae, Orobanchaceae, Acanthaceae, Plantaginaceae, Scrophulariaceae, Solanaceae, Papaveraceae, Saxifragaceae, and Myricaceae.

Scots pine blister rust is widely distributed across Europe and Asia. Both the heteroecious and the autoecious forms of C. pini cause severe damage on pines (Fig. 2), where they produce branch and stem lesions. Lesions caused by the heteroecious form typically kill the tree more rapidly than those caused by the autoecious form. The rust is most severe on Scots pine and several of the Mediterranean pine hosts. Scots pine blister rust has been reported in widely ranging Eurasian countries including Armenia, Austria, Azerbaijan, Belgium, Bosnia and Herzegovina, Bulgaria, Croatia, Czech Republic, Denmark, Estonia, Finland, France, Georgia, Germany, Great Britain, Greece, Hungary, Italy, Kosovo, Latvia, Lithuania, Macedonia, 
Montenegro, Netherlands, Norway, Poland, Portugal, Romania, Russia (from Europe to far eastern Russia), Serbia, Slovenia, Spain, Sweden, Switzerland, Turkey, and Ukraine (CABI 2020, Özkazanç and Maden 2013). In Asia, a rust referred to as Scots pine blister rust is also found in Russia, China, Japan, Kazakhstan, Korea, and Taiwan (CABI 2020).

\section{GEOGRAPHIC DISTRIBUTION OF SCOTS PINE}

Scots pine (sometimes previously referred to as Scotch pine) is one of the most widely distributed conifers in the world. Its native range extends from Great Britain and Spain east through Siberia, south to the southern Caucasus region, and north to Lapland. Scots pine has been widely planted in New Zealand and the colder regions of North America, and it has become naturalized in the northeastern, midwestern, and Pacific northwestern United States. Scots pine is the only pine native to northern Europe and once formed much of the Caledonian Forest of the Scottish Highlands. In its northern distribution, it ranges from sea level to $914 \mathrm{~m}(3,000 \mathrm{ft})$ in the British Isles, whereas in its southern distribution, Scots pine grows at higher elevations, from 1,219 to 2,590 m $(4,000$ to $8,500 \mathrm{ft})$.

Scots pine trees can typically attain a height of $24 \mathrm{~m}(80 \mathrm{ft})$, a diameter in excess of

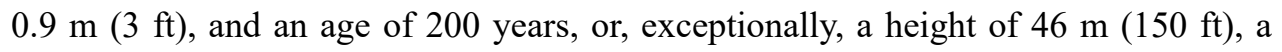
diameter of $1.7 \mathrm{~m}\left(5 \frac{1}{2} \mathrm{ft}\right)$, and an age of 700 years. Scots pine requires full sun and the absence of excessive grazing to establish from seed, and it can quickly invade disturbed areas. In the United States, Scots pine has been planted for erosion control, ornamental purposes, and pulp/timber production; however, its primary economic value is currently

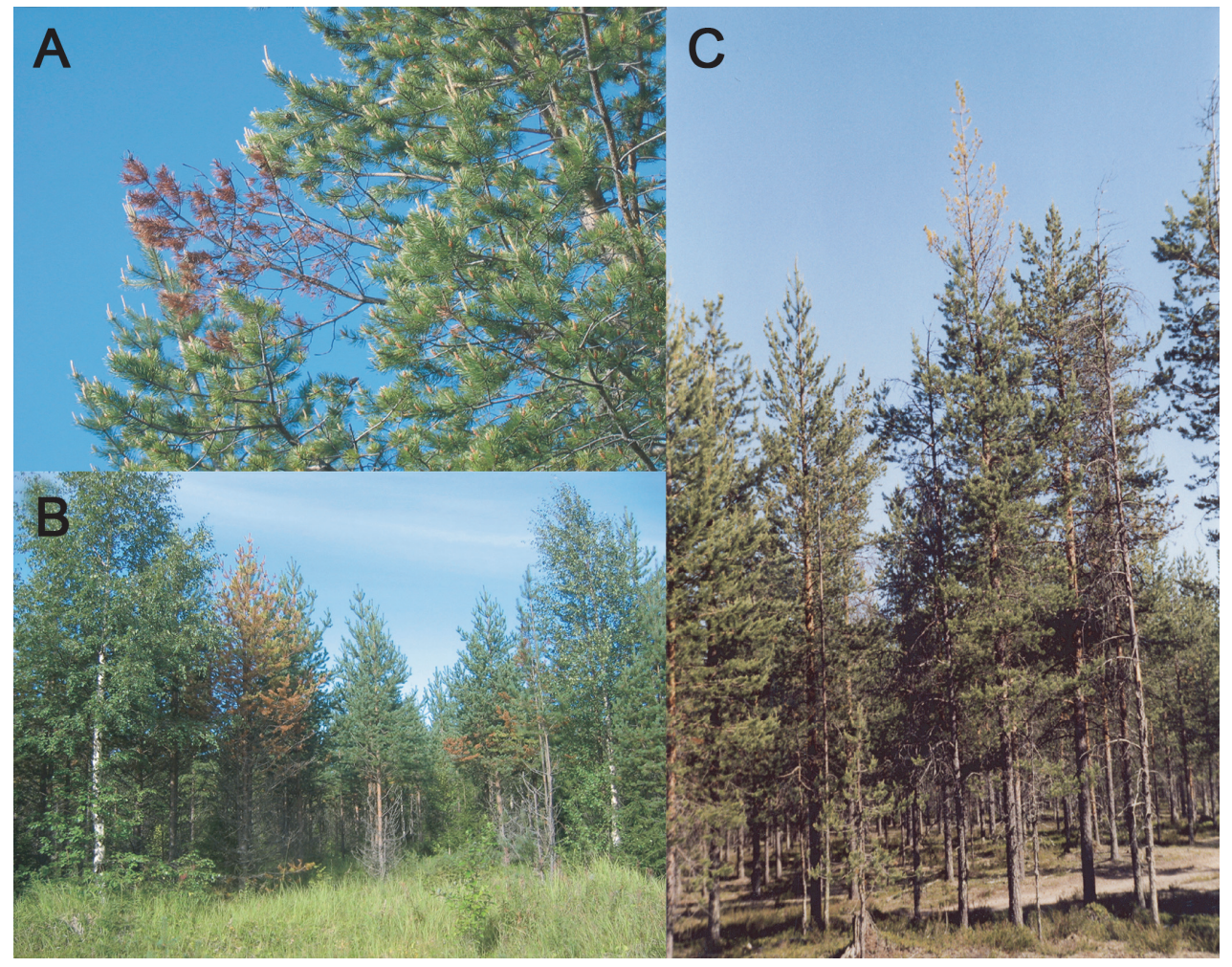

\section{FIGURE 2}

Damage caused by Cronartium pini on Scots pine (Pinus sylvestris). A, Branch mortality caused by the heteroecious form, where the branch tip has died distal to a branch lesion. B, Tree mortality caused by the heteroecious form, where the tree has been killed above a stem lesion. C, Rust damage caused by the autoecious form. In the center, the stem leader of the tree has been killed above a stem lesion, while the lower canopy is still alive. On the right, a whole tree has been killed by Scots pine blister rust. An old stem lesion where sporulation occurred, which is blackened and resinous, is located on the lower stem. (Photos by Juha Kaitera.) 
as Christmas trees (Agricultural Marketing Resource Center 2008), although other conifers are becoming more favored, recently.

\section{NOMENCLATURE/TAXONOMY OF SCOTS PINE BLISTER RUST}

The rust fungi (Basidiomycota: Pucciniomycetes: Pucciniales) are a large, diverse group of biotrophic fungi that reproduce only in living plant tissue, containing the family Cronartiaceae, which comprises three genera (Cronartium, Endocronartium, and Peridermium). Among the many important plant pathogens in this group are the pine stem rust fungi Cronartium and Peridermium. The taxonomy of the Scots pine blister rust pathogen has been particularly confusing, owing to a relationship between the host-alternating and pine-to-pine forms that were previously known as C. flaccidum and P. pini (E. pini), respectively. Foresters and mycologists have long recognized the similarity of the rust diseases caused by these fungi and the apparently identical morphology of their spores produced on infected pine stems and branches. The main difference between the pineborne spores of the two rust fungi is their infection of flowering plants and pines versus sole infection of pines. Hiratsuka (1968) reported developmental differences in spore germination (and life cycle), which prompted him to name the pine-to-pine form Endocronartium pini. However, molecular evidence points to a very close evolutionary relationship between these rust pathogens (e.g., Vogler and Bruns 1998). Hantula et al. (2002) provided morphological and molecular evidence demonstrating Scots pine blister rust pathogens as a single species with alternative life cycles. Later, other population studies also confirmed that Scots pine blister rust pathogens belong to a single species (Samils et al. 2011, 2021). As a consequence, the two forms of C. pini have not been differentiated by presently available DNA sequence analyses or aeciospore morphology, although an analysis of homozygotic/heterozygotic loci can potentially differentiate the rust pathogen forms in the aecial stage (Kasanen 1997). Although the morphology of the Scots pine blister rust pathogen shares some similarities to other rust pathogens, DNA sequences (e.g., internal transcribed spacer [ITS]) of the Scots pine blister rust pathogen are distinct from other known rust pathogen species. For this reason, the Scots pine blister rust pathogen could be detected by molecular means for quarantine control.

Recently, the Scots pine blister rust fungus has been renamed as C.pini (Willd.) Jørstad (Species Fungorum 2021; Wijesinghe et al. 2019). In this review, we refer to Scots pine blister rust without distinguishing between its life-cycle forms. However, the Scots pine blister rust form is reported when specific studies pertain to a specific lifecycle form.

\section{Biology and Symptoms}

\section{LIFE CYCLE}

A typical Cronartium species that alternates between pine and angiosperm hosts has five spore stages; nomenclature, morphology, and nuclear condition given here are from Cummins and Hiratsuka (2003) (Fig. 3).

Stage 0: Spermatia - borne in spermogonia. Spermogonia are hermaphroditic structures containing female receptive hyphae and male spermatia. Spermogonia occur in the outer pine stem cortex under the host periderm and produce spermatia in a sugary fluid, which is attractive to insects.

Monokaryotic haploid (n) spermogonia produce haploid, uninucleate spermatia that are small, thin-walled, and globose to flask-like in shape. Spermatia are transferred by insects to other spermogonia, where, following union with a receptive hypha, a dikaryotic $(n+n)$ mycelium is produced that eventually produces aecia.

Stage 1: Aeciospores-borne in aecia. Aecia develop in the stem cortex of a host pine and are often associated with hypertrophy of the stem tissue. The aecium is a structure that produces chains of binucleate, warty, thick-walled, pigmented aeciospores that are bordered by a prominent papery peridium. The host cortex ruptures as the aecia 
mature, the peridium ruptures, and aeciospores are released. Aeciospores are dispersed aerially, and, following germination, produce a dikaryotic mycelium in angiosperm plant species that serve as alternate hosts.

Stage 2: Urediniospores-borne in uredinia. Urediniospores, like aeciospores, are dikaryotic. Urediniospores and aeciospores both infect the nonpine hosts through stomata and give rise to a mycelium that can form uredinia or telia. However, urediniospores can cause a repeating cycle of infections on the nonpine hosts without a sexual stage. The uredinium develops from subepidermal mycelium, and urediniospores erupt through the epidermis. Urediniospores are spiny, borne individually, and aerially dispersed.

Stage 3: Teliospores-borne in telia. The telium arises from subepidermal, heterokaryotic hyphae that may have previously produced urediniospores, and develops into an erumpent, hair-like column of dark, thick-walled teliospores on the nonpine host. Teliospores are not dispersed but are the site of karyogamy and produce metabasidia ( $2 \mathrm{n}$ ) that undergo meiosis, leading to formation of an elongate, septate basidium and basidiospores.

Stage 4: Basidiospores—borne on basidia. Basidiospores are globose, thin-walled, haploid (n) spores that develop on projections of the basidia called sterigmata, which aid forcible ejection of the basidiospores. Basidiospores are discharged away from the telium and dispersed in moist air currents to a pine host needle or shoot. Basidiospores germinate and infect pine needles through stomata. The haploid mycelium grows down the needle and into the stem; when the mycelium reaches sufficient quantity and density, spermogonia will be produced to complete the cycle.

Cummins and Hiratsuka (2003) describe the life cycle of $P$. pini as endocyclic and justify their nomenclature of $E$. pini. In this case, spores that morphologically resemble

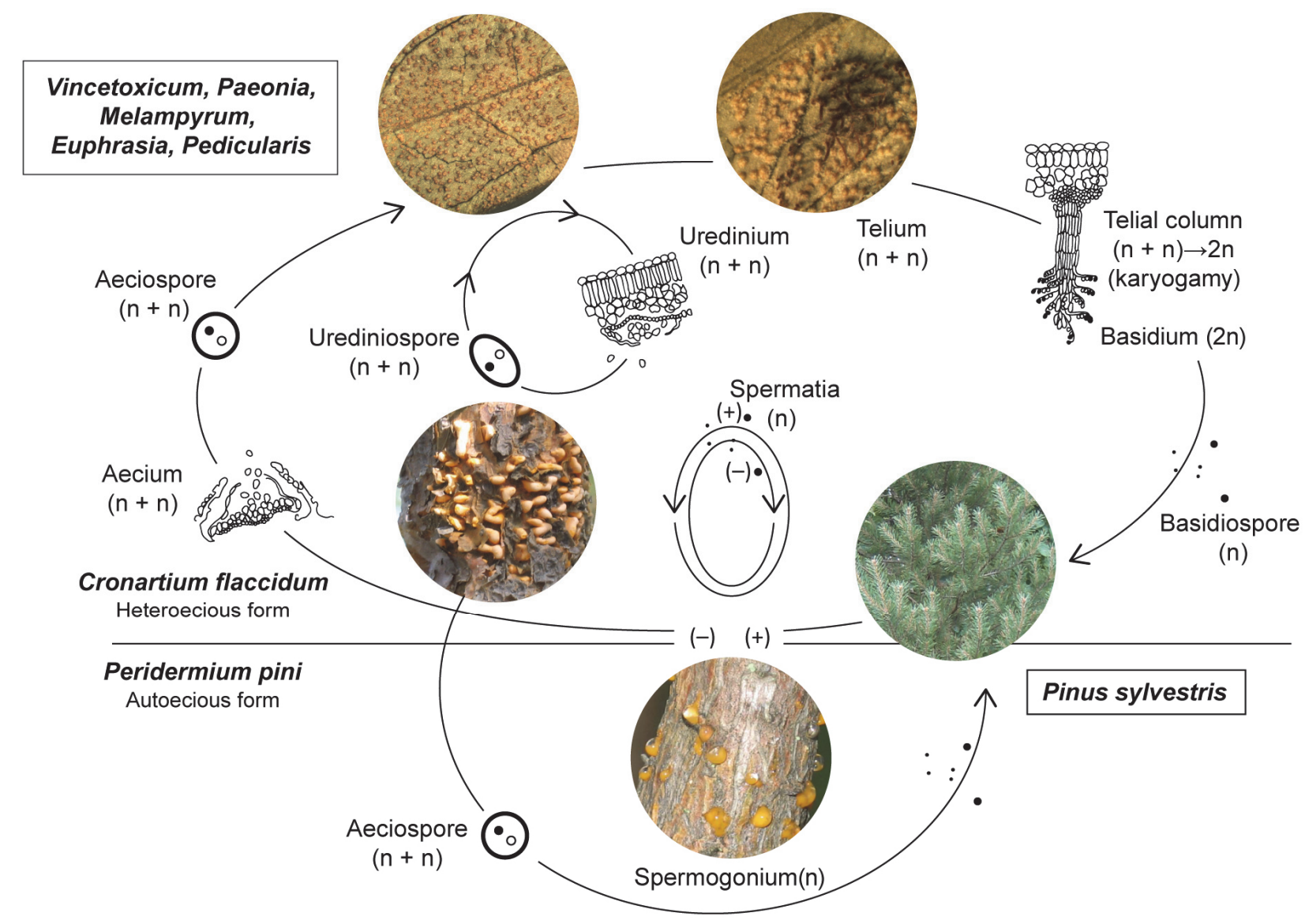

FIGURE 3

Scots pine blister rust (Cronartium pini) disease cycle. 
aeciospores are produced on the pine host, dispersed, and directly infect other pines. Spermogonia may also be produced.

The heteroecious form of Scots pine blister rust infects a host pine through needle stomata (Ragazzi and Dellavalle Fedi 1992), but symptoms on the branch or main stem only become apparent later in development. Infection of the autoecious form can also occur through wounds (Kaitera and Nuorteva 2008). In pine, the Scots pine blister rust fungus produces several types of reproductive structures that are observed as either tiny sacs of a sugary "nectar" with spermatia (Fig. 4A) or small, white, or light orange bladders (Fig. 4B) filled with powdery, orange-colored aeciospores. Both the heteroecious and autoecious forms produce spermogonia and aecia. Spermogonia usually form within a swelling of the phloem, 1 year (autoecious form) to 2 years (heteroecious form) after infection (Kaitera and Nuorteva 2008). Aecia formation follows a year after the spermogonia are produced, and aecia formation can last in the same lesion for up to 8 years (Kaitera 2003). Diseased branches become swollen; after release of the aeciospores, the bark cracks, darkens, and the end of the branch is killed if the branch becomes girdled. Infection in a main stem by the Scots pine blister rust pathogen can also produce spermatia and aeciospores. The disease first appears as a diamond-shaped, resinous canker, and eventually girdles the stem, which kills the distal part of the branch or acropetal portion of the stem. Insects carry spermatia among Scots pine blister rust cankers of diseased pines and aid in fertilization. After formation of spermogonia, aeciospores can develop in aecia several years after fertilization. Aeciospores are released in summer, and they can be wind carried for long distances to infect a suitable host. The Scots pine blister rust pathogen grows downwards in a pine stem $>10 \mathrm{~cm}$ (several inches) per year. Small trees are killed within several

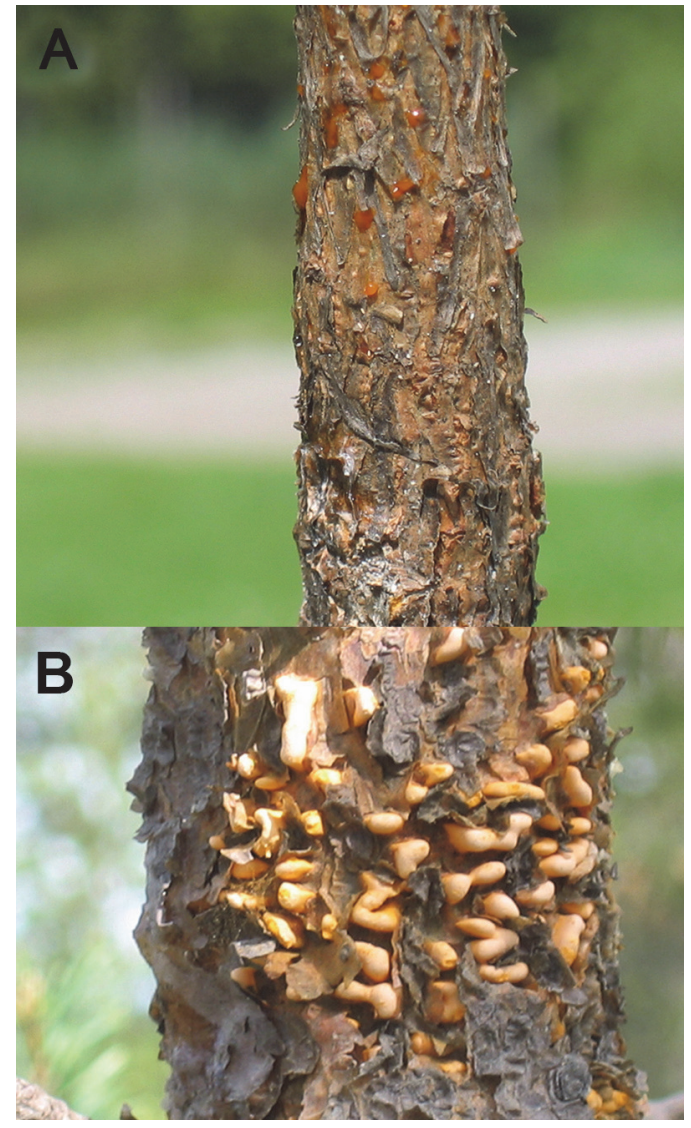

FIGURE 4

A, Spermatial droplets of the heteroecious form of Cronartium pini on Scots pine (Pinus sylvestris). B, Aecia of the autoecious form of C. pini on Scots pine. (Photos by Juha Kaitera.) years of infection; larger trees are often infected in the middle of the crown, so if not killed by a girdling, resinous canker, an infected tree may persist for decades with a dead top, hence the name "resin-top disease" (Fig. 2).

\section{Spread and Climate-Host Suitability Map}

\section{SPREAD OF THE SCOTS PINE BLISTER RUST PATHOGEN}

Although natural spread of the Scots pine blister rust pathogen is principally via aerial dispersal, important differences between the two life-cycle forms of the rust pathogen determine if infection occurs pine-to-pine or through an alternate host. Infection of a pine by the heteroecious form eventually results in production of specialized structures (spermogonia) that mediate cross-fertilization (genetic exchange) by transfer of insect-vectored spermatia to the receptive hyphae of a separate infection. In late spring through summer, hyphae fertilized in the previous year form blister-like aecia with yellow-pigmented, thick-walled aeciospores that aerially disseminate the rust pathogen to the alternate host. Although most dispersal is likely limited to within $\sim 10 \mathrm{~km}(\sim 6$ miles) and is mostly much closer, a very small proportion of aeciospores may be carried $>300 \mathrm{~km}$ ( $>200$ miles) from the parental canker. The first spore stage produced on alternate hosts, uredinia with urediniospores (Fig. 4), may increase infection on the same or different alternate host plants, which can result in further rust pathogen dispersal. More importantly, the uredinial stage can produce a large, nonsexual amplification of inoculum under some environmental conditions, such as increased temperature and/or moisture during critical periods that promote uredi- 
niospore amplification. In late summer or early autumn, another spore stage, the teliospore, is produced. The teliospores produce the final spore stage, the basidiospores, which are ejected into the air and dispersed by the wind. Because basidiospores are delicate, they are usually dispersed $<10 \mathrm{~km}(\sim 6$ miles), but typically for much shorter distances. If a viable basidiospore lands on a pine needle, germinates, grows into the needle (usually through a stomata), and avoids a resistance response by the host, the pine becomes infected. Although interpretations of the sexual process in the pine-to-pine form have varied, this form's initial stages resemble spermogonia and aecia, with the difference that its aeciospores infect a pine host directly, without intermediate stages on alternate hosts.

Alternate hosts of the Scots pine blister rust pathogen reside in diverse angiosperm families and genera. Based on inoculation tests in Finland, the genera Loasa, Nemesia, Melampyrum, Tropaeolum, Vincetoxicum, Pedicularis, and Paeonia are all reported as alternate hosts of the Scots pine blister rust pathogen (Kaitera et al. 1999). Kaitera and Nuorteva (2003a) reported that C. pini produces uredinia and telia on Melampyrum nemorosum and on Finnish Vincetoxicum hirundinaria. Elsewhere in Europe, evidence is growing that $C$. pini commonly spreads in nature on other alternate hosts in the cowwheat family of herbaceous plants (Melampyrum spp.) (Kaitera et al. 2005). Newly described hosts within the Melampyrum genus are M. pratense, M. nemorosum, and M. arvense. Previously known alternate hosts are $V$. hirundinaria (swallow-wort) (Fig. 5) and M. sylvaticum (small cow-wheat). Other susceptible species have been observed in the genera Veronica (Kaitera et al. 2015, 2018), Hyoscyamus (Kaitera et al. 2015), Nicotiana (Kaitera et al. 2015), Bartsia (Kaitera and Hiltunen 2012; Kaitera et al. 2012), Rhinanthus (Kaitera et al. 2015, 2018), Euphrasia (Kaitera et al. 2012, 2018), Castilleja (Kaitera et al. 2015), Odontites (Kaitera et al. 2018), Saxifraga (Kaitera et al. 2015, 2018), Myrica (Kaitera et al. 2012, 2015), Caiophora (Kaitera et al. 2012), Asclepias (Kaitera and Hiltunen 2012), Apocynum (Kaitera et al. 2015), Swertia (Kaitera et al. 2015, 2018), Impatiens (Kaitera et al. 2012, 2015), and Papaver (Kaitera et al. 2018) (Fig. 5).

\section{CLIMATE-HOST SUITABILITY MAPPING OF SCOTS PINE BLISTER RUST}

A climate-host suitability map for Scots pine blister rust pathogen was created based on the temperatures required for germination of $C$. pini aeciospores. The temperature range of $C$. pini aeciospore germination was previously determined as 5 to $30^{\circ} \mathrm{C}$, and telia formation was enhanced by precipitation (Ragazzi 1983; Ragazzi et al. 1986). The areas with suitable weather conditions were characterized using tools within the Spatial Analytic Framework for Advanced Risk Information Systems (SAFARIS) and PRISM climatic data from 2000 to 2019 (PRISM 2021; SAFARIS 2021). In addition, the distribution of Pinus species was incorporated in the climate suitability map. The map represents a combination of pine distribution (including all Pinus species and assuming

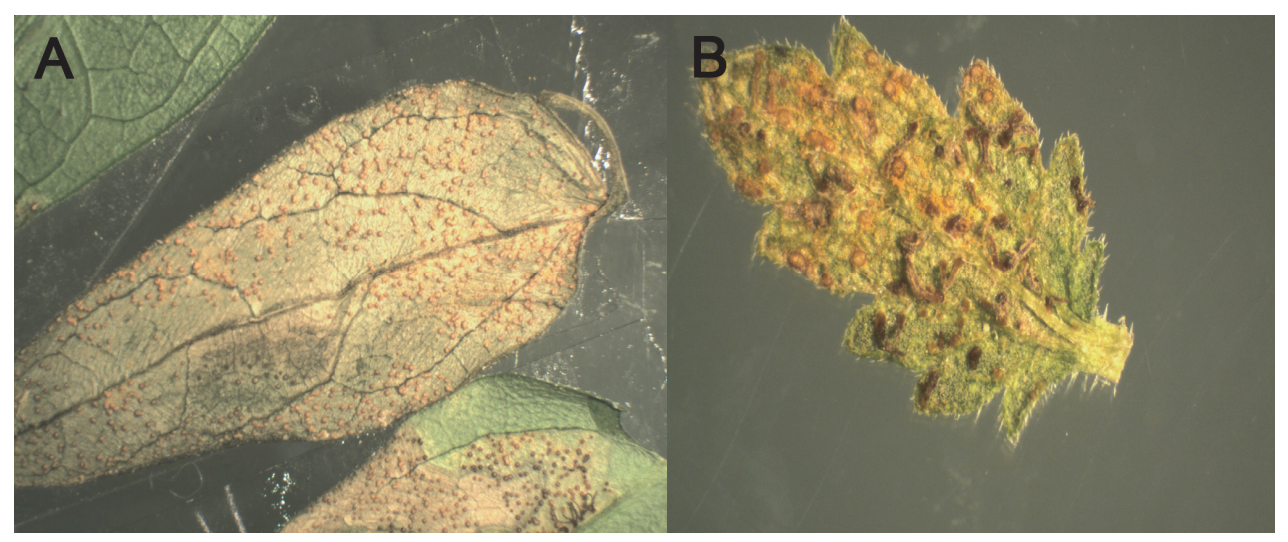

FIGURE 5

Uredinia and telia of the heteroecious form of Cronartium pini on Vincetoxicum hirundinaria (swallow-wort) (A) and Euphrasia officinalis (B). (Photos by Juha Kaitera.) 
equal susceptibility for all Pinus species) and incidence of perceived weather that is considered favorable for infection (Fig. 6). However, caution is warranted in interpreting this model because it does not account for differences in different pine species' susceptibility to and host suitability for Scots pine blister rust. Furthermore, this model does not incorporate information associated with potential alternate hosts of C. pini. An improved prediction model based on more accurate host and climate data would more precisely predict geographic areas at risk from C. pini infection.

\section{Monitoring, Detection, and Identification}

Although widespread in Eurasia, Scots pine blister rust has not been found in North America. Thus, exclusion of $C$. pini is the first line of defense to protect North America from Scots pine blister rust. Preventing the introduction of C. pini will require effective monitoring and detection procedures. Based on past introductions of plant pathogens, importation of infected primary or alternate host material represents the most likely pathway of introduction. Host materials, such as whole plants or leaf and stem tissue from the host plants listed above, represent the highest risk for harboring the pathogen. Pinus thunbergii Parl. (Japanese black pine), mugo pine or other two- or three-needled pines, commonly used for bonsai, pose a significant risk if imported as whole plants.

Scots pines in each region of the United States should be routinely monitored to detect any outbreaks of Scots pine blister rust. The United States Departments of Agriculture (USDA) Animal and Plant Health Inspection Service (APHIS) should be requested to include Scots pine blister rust in their diseases of special interest for inspections of nurseries and Christmas trees. State, federal, and private organizations should be requested to inspect for Scots pine blister rust in Scots pine forest and resource conservation plantings. These requests should be accompanied by descriptions of the disease (symptoms, signs, biology), a sampling protocol, and a list of laboratories equipped to provide reliable identification of the pathogens. The USDA APHIS Coop-

Scots Pine Blister Rust: Cronartium pini (Willd.) Jørstad

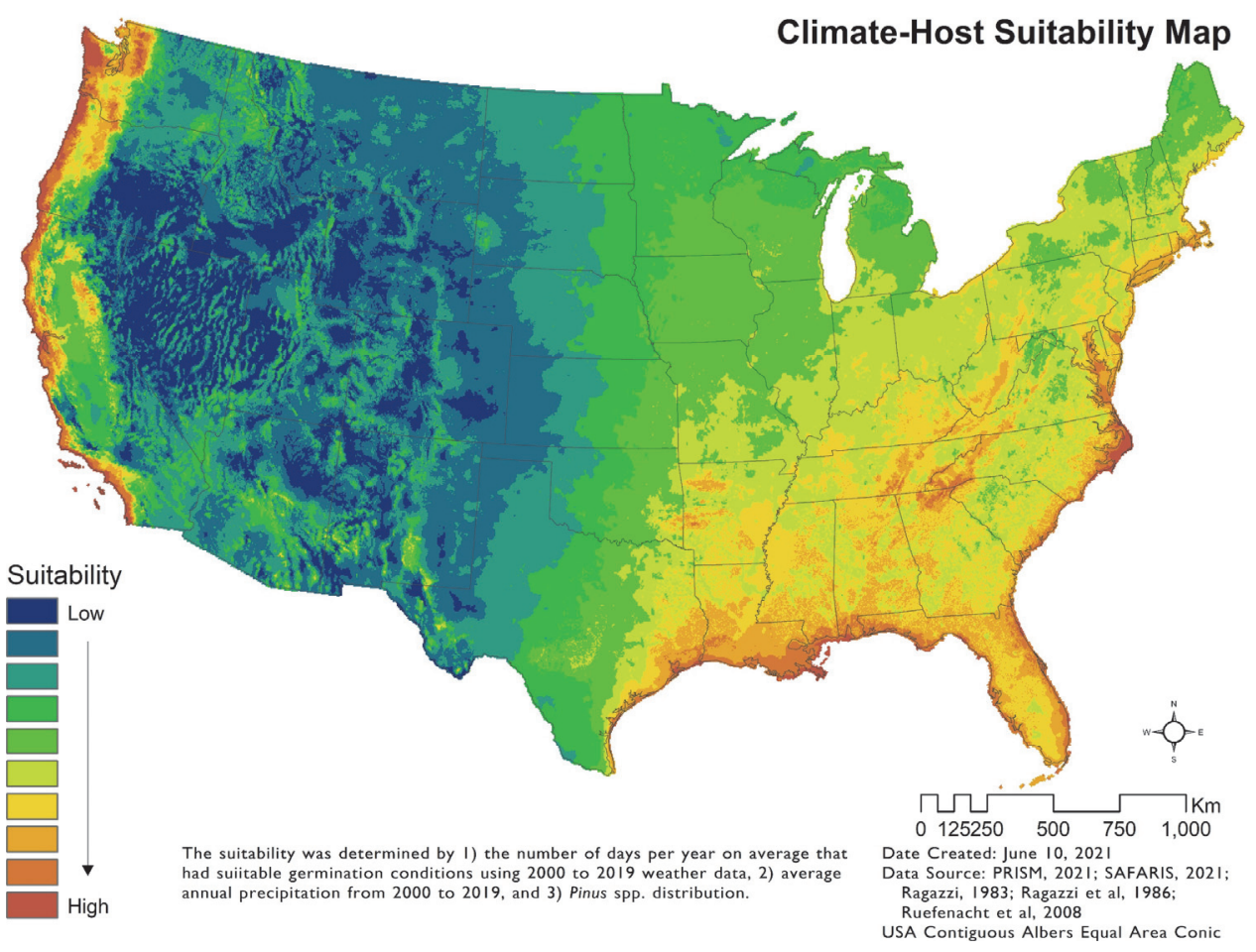

FIGURE 6

Climate-host suitability for Scots pine blister rust (Cronartium pini) in the contiguous United States. 
erative Agricultural Pest Survey Program (https://www.aphis.usda.gov/aphis/ourfocus/ planthealth/pest-detection) and Forest Service Forest Health Monitoring Program (https://www.fs.fed.us/foresthealth/protecting-forest/forest-health-monitoring/) should collaborate with state Departments of Agriculture for monitoring and detecting Scots pine blister rust. USDA Extension programs (https://nifa.usda.gov/extension) at Land Grant Universities should also be employed to educate growers and landowners.

Early detection of Scots pine blister rust at port facilities represents the first and best defense against introduction. The safest policy would be to prohibit the importation of primary and alternate host plants and plant parts into North America; however, the importation of host plant seed would represent only minimal risk for carrying C. pini. Pinus spp. seed is allowed to be imported into the United States from all countries.

Perennial host plants that are regulated as prohibited or as Not Authorized Pending Pest Risk Analysis (NAPPRA) are imported under a USDA APHIS Controlled Import Permit (PPQ588: https://www.aphis.usda.gov/aphis/ourfocus/planthealth/importinformation/permits/plants-and-plant-products-permits/prohibited/cip). Scots pine plants imported under this permit are required to follow quarantine procedures outlined in the permit. Quarantine procedures allow time for symptoms and signs of $C$. pini infection to develop, which may not have been expressed at the time of importation; quarantined plants that manifest signs or symptoms of C.pini infection must be destroyed according to USDA-APHIS-PPQ regulations. A thorough visual inspection of signs and symptoms of Scots pine blister rust should be conducted under a controlled environment (i.e., a biological containment greenhouse or a type II biological safety hood). Pine host symptoms include fusiform-shaped swelling (Figs. 4 and 7), resinosis of stem or branches (Fig. 7A), and/or yellow flecking of needles. Primary host signs include sticky, yellow, malodorous spore nectar and/or yellow-orange pustules on the stem or branches, and/or powdery yellow-orange spores (Fig. 4). Symptoms on angiosperm hosts include small spots (1 to $4 \mathrm{~mm}$ across) of yellow or lighter green than surrounding tissues on the underside of leaves. Angiosperm host signs include orange pustules (uredinia) or hair-like fungal structures (telia) protruding from the underside of leaves (Fig. 5). Visual diagnoses can be made with a hand lens or dissecting microscope; however, signs and symptoms may be latent for 3 to 4 years in infected pine host material and for up to a month in leafy alternate hosts. Nonsymptomatic infections could be easily overlooked by visual inspections, especially upon arrival of recently infected materials.

\section{DIAGNOSIS OF THE PATHOGEN}

Morphological features of aeciospores and/or urediniospores of $C$. pini are not specific enough to allow rapid identification of this rust pathogen species, but identification can be accomplished with DNA sequence-based tools (Hantula et al. 2002). Rust spores, whether collected from leaves, cankers, aecia, or uredinia (from the host/alternate host), spore traps, or washes from plants, would first be subjected to DNA extraction prior to subsequent analyses. Aeciospores have a thick outer wall, and DNA extractions can be conducted using a CTAB method (Chen et al. 1993; Samils et al. 2021). Several approaches have been used and/or developed to distinguish

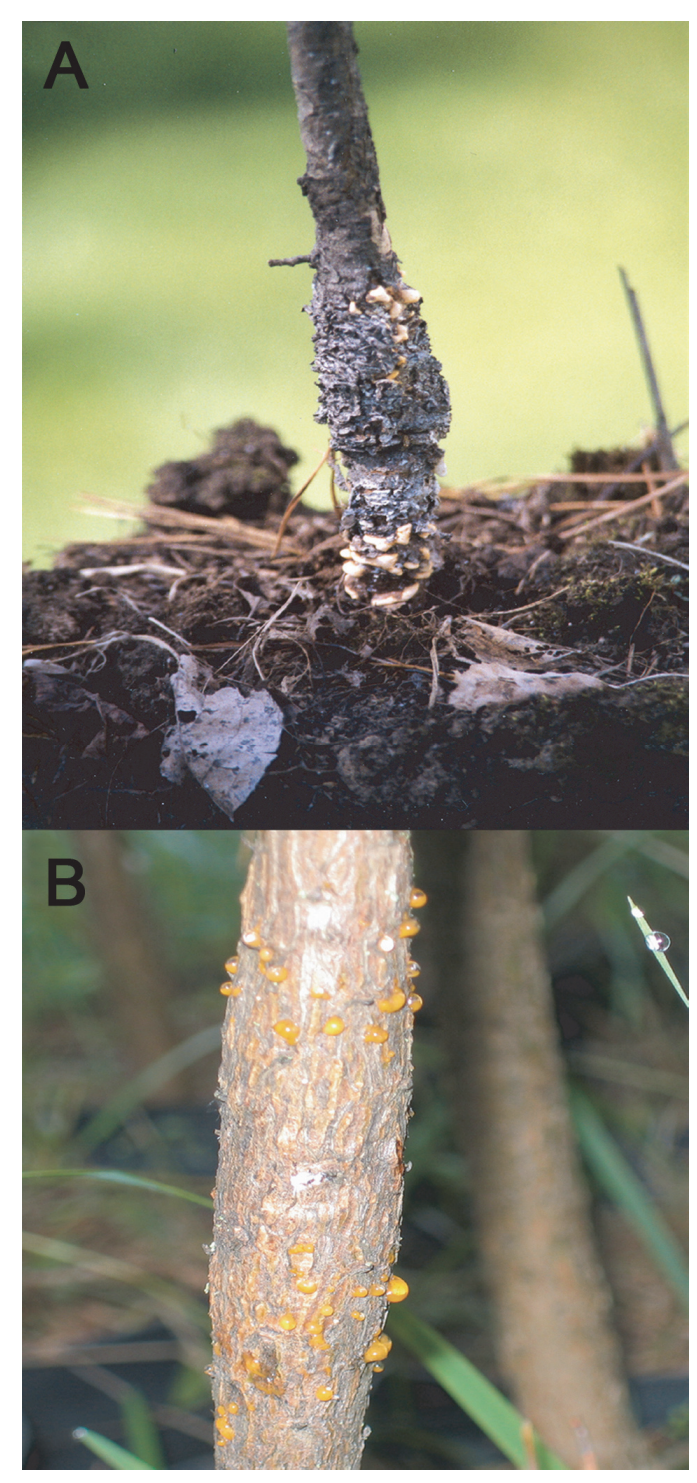

FIGURE 7

A, Old sporulated lesion with new aecia of the autoecious form of Cronartium pini on Scots pine (Pinus sylvestris). B, Swelling with spermogonia of the heteroecious form of $C$. pini on Scots pine. (Photos by Juha Kaitera.) 
C. pini from other Cronartium/Peridermium species, yet species-specific identification tools have not yet been developed for $C$. pini. A common method for C. pini identification is based on Sanger sequencing of ribosomal DNA regions, including the ITS2 and intergenic spacer (IGS)-1. The ITS2 and IGS-1 regions can be amplified using polymerase chain region (PCR) with primers Rust3 and ITS4 (Moricca and Ragazzi 1998; White et al. 1990) for the ITS2 region and H and 5B (Buchko and Klassen 1990; Moricca and Ragazzi 1998) for the IGS-1 region. Generated sequences are then compared with sequences within databases, such as the National Center of Biotechnology Information (NCBI) database (https://blast.ncbi.nlm.nih.gov/Blast.cgi), using BLAST algorithms to determine similarity of sequences to reference sequences of known and verified rust species. Using currently available tools and techniques, detection of C. pini could require a few days or even weeks. Development of species-specific molecular tools, including quantitative PCR (qPCR), loop-mediated isothermal amplification (LAMP) detection, or antibody-based assays would help to identify $C$. pini more rapidly in newly invaded geographic regions. Microsatellite markers, Pp1 and Pp2, could be used for identification and gaining a better understanding of genetic diversity of C. pini across geographic regions. These microsatellite markers were first developed by Kasanen et al. (2000), and these markers were subsequently adapted by Samils et al. (2011) to allow amplification of the shorter simple sequence repeat amplicons. Using these markers and amplified fragment length polymorphism (AFLP), Samils et al. (2021) identified six genetically distinct Bayesian clusters across 14 sampled locations in Finland and Sweden.

\section{Response}

The response to all plant health emergencies in the United States is under the authority of USDA-APHIS-Plant Protection and Quarantine (PPQ) delegated by the Secretary of Agriculture under the Plant Protection Act of 2000.

If a detection of $C$. pini were confirmed by a USDA-APHIS-PPQ recognized authority, APHIS would be in charge of the state(s) where detection has occurred. For typical first detections of an exotic pathogen, response would begin with an initial assessment. For a nursery site, a Rapid Assessment Team (RAT) consisting of state and federal experts on Cronartium and associated regulatory personnel may be deployed on-site to collect additional plant, soil, and water samples to conduct epidemiological investigations and initiate environmental delimiting surveys outside the nursery grounds. Possible actions include quarantines of infested or potentially infested production areas, prohibiting movement of infected or potentially infected materials in commerce, host removal and destruction, requiring adherence to sanitary practices, and application of registered fungicides and disinfectants. Trace-forward and trace-back surveys would be required for locations that have sent or received potentially infected nursery stock to/from the nursery with a confirmed pathogen detection. APHIS could impose quarantines and regulatory requirements to control and prevent the interstate movement of quarantinesignificant pathogens or regulated articles (high-risk host material), and APHIS works in conjunction with states that impose actions parallel to APHIS regulatory actions to restrict intrastate movement. The RAT would also attempt to ascertain if the introduction was intentional or accidental. If the organism in question is a select agent covered under the Agricultural Bioterrorism Act of 2002, federal and local law enforcement may be involved in the initial assessment to determine if a bioterrorism event or biocrime event has occurred.

The USDA-APHIS-PPQ response also depends on where C. pini is found (e.g., forest, plantation, or nursery) and how widespread it is based on the initial RAT assessment and associated delimitation surveys. For example, if C. pini were found in a pine plantation, attempts would be made to eradicate the pathogen through several measures including plant destruction/eradication, soil/surface disinfestation, trace-forwards, and 
trace-backs similar to management of Phytophthora ramorum in the United States (Rizzo et al. 2005). Likewise, the practicality of eradication in a forest setting would be assessed by the RAT and a technical working group of Cronartium experts, and a recommendation will be made as to the potential for eradication of the infestation on a case-by-case basis.

\section{USDA Pathogens Permits and Regulatory Issues}

USDA-APHIS-PPQ permits for plant pests and biological control organisms fall under the authority of the Plant Protection Act, codified under 7 CFR 330. A PPQ 526 Permit is required for importation and interstate movement of all plant pests and infected plant materials, including diagnostic samples, regardless of their quarantine status. The receiving person must have been granted an authorized permit. Information on PPQ 526 Permits can be found at https://www.aphis.usda.gov/aphis/ourfocus/ planthealth/import-information/permits/regulated-organism-and-soil-permits. Applicants may also contact PPQ Permit Services at telephone (301) 734-0841, toll-free number (866) 524-5421, or e-mail Pest.Permits@usda.gov.

USDA-APHIS regulates the importation of Pinus species. Pinus spp. are Not Authorized Pending a Pest Risk Analysis (NAPPRA) (https://www.aphis.usda.gov/aphis/ ourfocus/planthealth/import-information/permits/plants-and-plant-products-permits/ plants-for-planting/ct_nappra) and are prohibited from importation into the United States from all countries except Canada, Japan, and South Korea (effective on May 20, 2013). Importation of two- and three-needled pines are prohibited from Japan and Korea with C. pini (listed as C. flaccidum) listed as one of the USDA pests of concern (https:// www.aphis.usda.gov/aphis/resources/farmbill/fb-pests/farmbill-pest-list).

\section{Economic Impact and Compensation}

Economic impacts are difficult to estimate and are dependent on the nature of the introduction and introduction pathways and the pathogenicity/virulence of the introduced C. pini on native and exotic plant species. If Eurasian pine species remain the only hosts of Scots pine blister rust in North America, the greatest economic impacts will be largely limited to nurseries and Christmas tree plantations that grow Scots pine and to cities and homeowners that will bear the cost of removal of dead or hazardous landscape and urban trees.

Restrictions on moving potentially infected hosts and eradication of infected materials in nurseries and Christmas tree farms could cause enormous economic losses amounting to millions of U.S. dollars. According to the National Christmas Tree Association, Scots pine is one of the most planted commercial Christmas trees in North America. Currently, Oregon, North Carolina, Michigan, Pennsylvania, Wisconsin, Washington, New York, and Virginia are the top Christmas tree-producing states in the United States. Most Scots pine is grown primarily in the Lake States, with Michigan and Wisconsin as the top producers of Christmas trees. Scots pine is one of the top five species of Christmas trees sold in the United States, although it is difficult to obtain an exact value for the Scots pine market. According to the Census of Horticultural Specialties in the United States, nearly 2,857 operations sold 11.7 million Christmas trees valued at \$357.1 million in 2019.

Impacts will depend on how widespread the introduction is, how fast spread might occur among areas where Scots pine has been planted, and whether or not measures to control spread are implemented. Because Christmas trees have a much shorter production cycle (compared with the life cycle of pine trees in forests), some areas that are slow to be affected by the introduced rust pathogen could transition to other, more resistant or immune conifer species or genotypes before losses from Scots pine blister 
rust or restrictions in tree movement impact the local Christmas tree production operations.

A worse-case scenario would be if $C$. pini already possesses or gains the capacity to infect native North American pines, which is not completely unexpected, given the large known host range of the pathogen on pine and nonpine hosts. C. pini is known to infect several aecial hosts. Based on previous inoculation tests, aecial hosts appear to be primarily restricted to select Eurasian two-needled pine species in the section Pinus (Kaitera and Nuorteva 2008; Mittempergher and Raddi 1977; Raddi and Fagnani 1978). Largely unsuccessful inoculations of North American pine species, section Trifoliae (ponderosa pine and P. contorta Douglas ex Loudon [lodgepole pine]) and section Pinus (red pine) have been reported (Kaitera and Nuorteva 2008; Raddi and Fagnani 1978), but successful artificial inoculations with C. pini are notoriously difficult. However, $C$. pini was able to cause needle spotting on some North American species. Needle spotting was found on lodgepole pine, P. echinata Mill. (shortleaf pine), P. elliottii Engelm. (slash pine), and red pine. In addition, mycelium was detected in needle tissue of ponderosa pine, but none of these North American pines supported the generation of pycnia (spermogonia) or aecia under the test conditions (Raddi and Fagnani 1978). Among native North American section Pinus species, resistance to Scots pine blister rust is apparently relatively high. Subsequent inoculation tests by Kaitera and Nuorteva (2008) also showed no symptoms on seedlings of Scots pine blister rust on lodgepole pine and red pine.

A likely route of potential C. pini invasion in North America could come from the widespread use of Scots pine, mugo pine, and Austrian/black pine in urban landscapes and Christmas tree plantations. These species are also naturalized in northern regions of the United States increasing the risk that an introduction could spread beyond urban landscapes, and providing the Scots pine blister rust pathogen with more opportunities to infect novel alternate hosts or to cycle directly back to Pinus (autoecious lifecycle). The presence of $C$. pini in North America could also conceivably provide more opportunities for this rust to jump to Pinus species in the section Trifoliae. Although previous inoculation tests show that native North American pine species appear to be at low risk for infection from C. pini, such inoculation tests cannot be conducted in the environment of North America, and environment will likely influence the pathogenicity of C. pini.

Another substantial threat is that $C$. pini could potentially hybridize with native pine rust pathogens that also have broad and overlapping alternate host range (similar to the detected rust hybrid in North America between introduced C. ribicola J.C. Fisch., cause of white pine blister rust, and native $C$. comandrae Peck, which causes a blister rust of lodgepole pine [Joly et al. 2006]). A scenario of $C$. pini or hybrids acquiring pine hosts that are currently resistant may also be possible. If such a scenario occurred, the economic and ecological impacts would be unpredictable, but potentially far greater than that posed by nonadapted or nonhybridized C. pini.

\section{Mitigation and Disease Management}

If Scots pine blister rust becomes sufficiently established and eradication is precluded, infested and threatened sites can be managed to mitigate impacts. Consistent restriction of $C$. pini dispersal and colonization would reduce further losses and restrict the ability of $C$. pini to adapt to its new environment and potentially new hosts. An understanding of Scots pine blister rust impacts on trees, populations, communities, and ecosystems is also useful for rehabilitation. The immediate objective of mitigation and management is efficient and effective minimization of damage to natural systems and loss of resource value. Activities range from disease control tactics, such as pruning, thinning, and removal of infected seed trees (trees grown for seed production), to program strategies, such as adaptive environmental assessment and management. Success- 
ful mitigation and management must confront with five principal issues: (i) long-distance, aerial dispersal of the Scots pine blister rust pathogen, (ii) multiple hosts of which many are (probably) unknown, (iii) differing objectives of various managers, (iv) a Scots pine blister rust pathogen that is capable of both sexual and clonal reproduction, and (v) a rapidly changing environment due to climatic, ecological, and socioeconomic factors.

\section{DISEASE CONTROL}

The life cycle of the Scots pine blister rust pathogen, C. pini, has vulnerabilities that can be exploited to prevent infection (by enhancing host escape) or minimize disease damage (influencing pathogen-host compatibility). General methods to control pine stem rusts include the use of chemicals to prevent infection, eradication or separation of alternate hosts from pine hosts, natural biological agents that reduce reproduction of the rust pathogen, and cultural management of host populations (silviculture) or individuals (arboriculture). Genetic manipulation can focus on selection, breeding, and deployment of hosts with greater resistance or tolerance to Scots pine blister rust disease.

Chemical controls might prevent host infection by the Scots pine blister rust pathogen and reduce pathogen vigor, viability, and inoculum production; however, few specific studies are reported for Scots pine blister rust. Control trials have included prophylactic chemicals to protect pines, salts and herbicides to kill alternate hosts, antibiotics to clear infections, and insecticides to control insect vectors. Triadimefon has been demonstrated to be a useful prophylactic for white pine blister rust (Pitt et al. 2006). Yao and Peixin (1991) report that application of Topsin and triadimefon to a canker surface was effective in eliminating aecial sporulation of Scots pine blister rust pathogen in China. Salt spray can kill alternate hosts, but eradication was only practical in proximity to a pine plantation and likely would require intensive applications. Maloy (1997) reviewed the history of control of C. ribicola in the United States, including abandoned efforts with antibiotics and herbicides. Pappinen and von Weissenburg (1996) describe how pine-top weevil wounding pine twigs increased Scots pine blister rust infection, which suggests that this disease could perhaps be managed in part by reducing pine-feeding insects. Studies on the effective use of insecticides to reduce insect vectors (that carry either spermatia or aeciospores) are apparently unavailable.

Control of pine stem rusts with biological agents has focused on rust canker-associated fungi that interfere with rust sporulation. Early work investigated Tuberculina maxima, which is a secondary fungus on cankers of many pine stem rusts caused by different pathogens, including Scots pine blister rust, but it has not been shown to be effective. Previous attention also focused on Cladosporium tenuissimum, which acts as an antagonistic hyperparasite. When suspensions of the mycoparasite Trichoderma atroviride were applied to C. ribicola aecia on P. armandii Franch. (Chinese white pine) in China, aeciospores were destroyed (Li et al. 2013).

Cultural activities provide numerous opportunities to mitigate damage by Scots pine blister rust. Although management for stem rusts must consider details of each specific pathosystem, general approaches developed for other Cronartium rusts and invasive tree pathogens have potential relevance (for a general review, see Waring and O'Hara 2005). Potential disease problems can often be avoided with careful matching of site and tree selection. Because some microclimates are more favorable for development of Scots pine blister rust and some sites have close proximity between uninfected trees and inoculum, hazard at some sites may be sufficiently high that alternative management, such as the use of nonhost species or host pines with adaptive traits (i.e., greater resistance) should be considered (Pei and Brodie 1995). In Finland, Kaitera and Nuorteva (2008) observed that susceptibility to $C$. pini infection varied among host provenances, with interactions with rust source and weather. In their study, lodgepole pine (native to North America) was not infected. Raddi and Fagnani (1978) also noted differences in susceptibility of Italian pines and some resistance in ponderosa pine (native to North America). The potential existence of different $C$. pini races with varying 
virulence among hosts must also be considered, although this feature has not yet been established.

Whether thinning to improve stand growth or removing diseased trees (sanitation or salvage), management practices can mitigate disease loss, depending on numerous interacting factors. Kaitera (2002) observed that thinning Scots pine did reduce C. pini infection compared with unthinned plots, but year-to-year variation was high in both thinned and unthinned treatments. Such results are not unexpected because thinning affects microclimate to increase foliage drying, which would likely decrease C. pini spore germination. Thinning can also increase dispersal of C. pini spores within a stand, enhance alternate host persistence, and result in wounding (a potential infection pathway). Generally, thinning, fertilization, and augmentation with mycorrhiza are considered beneficial to stand growth; however, these activities could also potentially increase Scots pine blister rust by increasing susceptible tissue. As with species preference, thinning effects on Scots pine blister rust are not simple to predict.

Pruning can remove infected branches before the rust pathogen enters the trunk, eliminate branches that may become infected later and lead to lethal trunk cankers, and improve wood quality as knot-free timber. In some situations, trunk cankers can be excised, rendered inactive by chemical or biological agents, and/or contained over time through host resistance reactions. Because pruning and individual canker treatments are labor-intensive and time-sensitive activities, the economics of treatment are important in determining whether this type of control is practical for saving individual trees, especially because significant reduction in inoculum should not be expected.

Although eradication of the alternate host has been effective for mitigating impacts of other rust diseases in certain regions, host eradication is generally not practical for Scots pine blister rust. The range of hosts that contribute to pine infection is large, diverse, and includes the pine itself in northern regions where the autoecious form prevails. Nonetheless, reducing the proximity of pine to alternate hosts can reduce but not eliminate $C$. pini infections, especially in sites where only heteroecious rust occurs. Genetic control tactics can be effective for future generations and can be implemented by favoring natural reproduction from less-diseased trees or outplanting seedlings from resistant parents. Variation in blister rust incidence among Scots pine provenances has been reported by Kaitera (2003), and some cultivars of some alternate host species are immune. Selection in natural stands or breeding programs can increase the frequency of resistance in the host, but the potential for $C$. pini evolution must also be considered. Designing and monitoring a genetic control tactic should therefore consider the several host-pathogen interactions of resistance, virulence, tolerance, and aggressiveness. Hybridization or genetic exchange among different rust pathogens or hosts could also affect the ability to reproduce or sustain disease (Brasier 2001). Although resistancebreeding programs (e.g., Murray 1964) are expensive due to management and associated research costs, they can provide not only improved seed but also valuable genetic information (Kinloch 1972). Federal cooperative genetic tree-improvement programs at several locations are currently addressing several pine stem rusts other than Scots pine blister rust.

Disease control tactics should be employed in a strategic context. Given the complexity and uncertainty of mitigating Scots pine blister rust and managing infested ecosystems for a novel disturbance, adaptive management is especially appropriate (Williams et al. 2009). Decisions over control (and monitoring) of pine stem rusts are frequently made with use of rust hazard models that typically provide landscape or stand projections of infection likelihood, incidence, or damage severity (e.g., Van Arsdel et al. 1961).

\section{RISK MANAGEMENT}

Even during the phase of mitigation and management, it is important to identify risk factors and consider alternative outcomes of treatment. The epidemiology and damage 
from Scots pine blister rust vary in space and time due to differences in climate, soil type, stand age, host species, growth, genetics, and other unknown factors (Greig 1987; Kaitera et al. 1994; Murray et al. 1969).

Risk management techniques (see U.S. EPA 2003; Lovett et al. 2006) provide procedures to incorporate complexity and uncertainty into hazard maps and simulation models. For example, a regional map of predicted severity of white pine blister rust based on synoptic climate, a lake effect, and alternate host distribution was developed by Van Arsdel et al. (1961). McDonald et al. (1981) developed an epidemiological simulation model for white pine blister rust that projects growth and mortality of P. monticola Douglas ex D.Don (western white pine) within infested stands that considered the abundance of hosts, climate, and site productivity. The potential influence of climate change on white pine blister rust has also been examined (Dudney et al. 2021). Such approaches, maps, and models can be useful where many complex factors must be considered in selecting a disease management regime.

Typically, rust-hazard assessments have been based on environmental and demographic processes without regard for evolutionary (e.g., genetic and environmental) interactions. The outcome of these interactions, however, can have profound effects on the naturalization of an introduced pathogen and the resulting condition of the affected ecosystem (see Parker and Gilbert 2004). An uncertain risk that increases the difficulty in planning mitigation is the potential for a pathogen to shift to a new host. Pedicularis and Castilleja are among several genera of flowering plants that are included as potential alternate host species of Scots pine blister rust. Although the susceptibility to Scots pine blister rust has not been determined for many species of Pedicularis and Castilleja endemic to North America, they are known hosts of other pine stem rusts and should be considered as potential hosts of Scots pine blister rust as well. The risk is not that North American populations of Pedicularis and Castilleja (or other alternate hosts such as Euphrasia and Rhinanthus) would be jeopardized, but that these alternate hosts could act as a $C$. pini inoculum source to infect pines or even serve as an alternate host for a hybrid rust pathogen. The North American pines, which are potential hosts of Scots pine blister rust, are also hosts of other, native pine stem rusts.

As mentioned, hybrids between a different Eurasian pine stem rust (C. ribicola) and a North American stem rust (C. comandrae) have been observed as sporulating aecia on pine at a few locations (Joly et al. 2006), but no alternate host has been reported for this rust hybrid. If Scots pine blister rust were established in North America, opportunities could occur that could facilitate hybridization of rust pathogens. Because of the pine and angiosperm host ranges and the conditions favoring C. pini infection, the likelihood and consequences of $C$. pini hybrid pathogens arising are difficult to predict (see Brasier 2001 for hybrids in nonrust pathogens).

\section{Research, Extension, and Education Priorities}

\section{RESEARCH PRIORITIES}

Many questions remain about the ecological behavior of the heteroecious and autoecious forms of $C$. pini even within its native range. Predicting actual impacts of Scots pine blister rust on potential hosts is a formidable task because of potential influences of host/pathogen genetic structure and the interaction of environment on virulence/resistance reactions. Although the Scots pine blister rust pathogen has been reported in eastern Asia, much less is known about the pathogen in eastern Asia than in Europe. Because great genetic variation could occur across the native ranges of C. pini and its hosts, research is needed to develop effective diagnostic techniques to characterize $C$. pini at the species, subspecies, and population levels, while also furthering our understanding the geographic distribution of the heteroecious and autoecious forms. Pathogen characterization is the initial step needed to assess variation in life cycle, host 
ranges, variation in virulence, and environmental optima for infection. Information gathered from such studies will allow improved predictions of geographic areas and host species at risk from C. pini.

Management of rust diseases often relies on resistance breeding programs, and this approach offers promise for Scots pine blister rust. Biological control also offers promise toward managing different forms of $C$. pini; therefore, continued research efforts are needed to identify biological control agents and associated techniques for enhancing biological control of Scots pine blister rust.

\section{Most Important}

- Determine if historical reports or herbarium records exist of rust disease on North American pines in historical European arboreta and other plantings where Scots pine blister rust occurs. A search for these records/ reports can initially focus on rust diseases on pine clades with a close phylogenetic relationship with Scots pine.

- Determine environmental conditions correlated with Scots pine blister rust distribution in Europe and Asia to allow more accurate risk assessments for North America.

- Use inoculation tests in infested countries to determine potential aecial and telial hosts of Scots pine blister rust in plants that occur naturally or are planted in North America.

- Conduct phylogenetic analyses of known and potential nonpine hosts of Scots pine blister rust.

- Develop prediction models of potential spread of Scots pine blister rust based on distribution of aecial and telial hosts combined with present and future climate models.

- Conduct phylogenetic analysis of the Scots pine blister rust pathogen (C. pini) and other pine stem rust pathogens present in North America (e.g., C. arizonicum Cummins, C. coleosporioides f. album Ziller, C. comandrae, C. ribicola, and P. harknessii J.P.Moore).

- Conduct population genetic analysis to determine the genetic diversity of C. pini across its native range.

- Determine the range of pine hosts and nonpine, alternate hosts, and environmental requirements for each genetic group of $C$. pini.

\section{Highly Important}

- Assess potential sources of Scots pine blister rust resistance in aecial host (pine) populations of North America.

- Begin assessments of potential biological control agents for Scots pine blister rust.

\section{Needs Evaluation}

- Evaluate potential genetic information and assess status of germplasm collections for diverse geographic sources of potential pine hosts of Scots pine bister rust in North America.

- Establish sentinel tree and alternate host plantings, preferably using known susceptible seed sources, in areas with Scots pine blister rust to help in early detection and establish a baseline of susceptibility against which the results from genetic screening can be compared.

\section{EXTENSION PRIORITIES}

Rust pathogens are difficult to identify reliably based solely on morphology and symptoms. Periodic surveys of rust on aecial and telial hosts should include sensitive (e.g., DNA-based) diagnostic protocols to identify rust pathogens, their hosts, and distribution. 
The following action items must be developed:

- Cooperate with National Plant Diagnostic Network (NPDN) to develop tree-rust diagnostic tools that accurately identify tree-rust pathogens.

- Conduct surveys of potential aecial and telial hosts using DNA-based diagnostic tests to identify rust pathogens.

- Develop means to prevent the introduction/spread of C. pini via movement of aecial and telial hosts.

- Develop and circulate educational materials describing Scots pine blister rust (symptoms, signs, biology), comparing it with rust diseases currently present, and describing the threats associated with introduction of the Scots pine blister rust pathogen.

\section{EDUCATION PRIORITIES}

- Educate plant pathologists, plant health professionals, extension agents, forest managers, nursery growers, Christmas tree growers, horticulturalists, general public, and associated entities about potentially invasive rust pathogens, including C. pini.

- Develop targeted education programs directed toward areas that may be at high risk for Scots pine blister rust, such as Christmas tree growers or horticultural nurseries.

- Engage Master Gardener and Master Naturalist programs and other relevant existing outreach programs to educate stakeholders about Scots pine blister rust and other potentially invasive tree rust pathogens.

- Integrate Scots pine blister rust into state and regional "pest detector" educational programs that focus on nonnative invasive pests.

\section{ACKNOWLEDGMENTS}

We thank the contributors (Drs. Brian W. Geils, Charles G. Shaw III, James Walla, Russ Bulluck, Laura Redmond, and Kent Smith) who provided inputs on the original version of this plan and Melissa Morley for graphic drawing (Fig. 3).

\section{References}

Agricultural Marketing Resource Center. 2008. Christmas trees. Agricultural Marketing Resource Center, Ames, IA. Retrieved 21 May 2021 from https://www.agmrc.org/ commodities-products/forestry/christmas-trees.

Brasier, C. M. 2001. Rapid evolution of introduced plant pathogens via interspecific hybridization. BioScience 51:123-133.

Buchko, B., and Klassen, G. R. 1990. Detection of length heterogeneity in the ribosomal DNA of Pythium ultimum by PCR amplification of the intergenic region. Curr. Genet. 18:203-205.

CABI. 2020. Cronartium flaccidum (Scots pine blister rust) in: Invasive Species Compendium. CAB International, Wallingford, U.K. Retrieved 21 May 2021 from https:// www.cabi.org/isc/datasheet/16148.

Chen, X. M., Line, R. F., and Leung, H. 1993. Relationship between virulence variation and DNA polymorphism in Puccinia striiformis. Phytopathology 83:1489-1497.

Cummins, G. B., and Hiratsuka, Y. 2003. Illustrated Genera of Rust Fungi. American Phytopathological Society Press, St. Paul, MN.

Dudney, J., Willing, C. E., Das, A. J., Latimer, A. M., Nesmith, J. c. B., and Battles, J. J. 2021. Nonlinear shifts in infectious rust disease due to climate change. Nat. Commun. 12:5102.

Gibbs, J., and Kaitera, J. 2018. Resin Top Disease. Page 65 in: Compendium of Conifer Diseases. E. M. Hansen, K. J. Lewis, and G. A. Chastagner, eds. APS Press, St. Paul, MN.

Greig, B. J. W. 1987. History of Peridermium stem rust of Scots pine (Pinus sylvestris L.) in Thetford Forest, East Anglia. Forestry 60:193-202.

Hantula, J., Kasanen, R., Kaitera, J., and Moricca, S. 2002. Analyses of genetic variation suggest that pine rusts Cronartium flaccidum and Peridermium pini belong to the same species. Mycol. Res. 106:203-209. 
Hiratsuka, Y. 1968. Morphology and cytology of aeciospores and aeciospore germ tubes of host-alternating and pine-to-pine races of Cronartium flaccidum in northern Europe. Can. J. Bot. 46:1119-1122.

Joly, D. L., Langor, D. W., and Hamelin, R. C. 2006. Molecular and morphological evidence for interspecific hybridization between Cronartium ribicola and C. comandrae on Pinus flexilis in Southwestern Alberta. Plant Dis. 90:1552.

Kaitera, J. 1999. Cronartium flaccidum fruitbody production on Melampyrum spp. and some important alternate hosts to pine. Eur. J. For. Pathol. 29:391-398.

Kaitera, J. 2002. Short-term effect of thinning on Pinus sylvestris damage and sporulation caused by Cronartium flaccidum. Scand. J. For. Res. 17:158-165.

Kaitera, J. 2003. Susceptibility and lesion development in Scots pine saplings infected with Peridermium pini in northern Finland. For. Pathol. 33:353-362.

Kaitera, J., Aalto, T., and Jalkanen, R. 1994. Effect of resin-top disease caused by Peridermium pini on the volume and value of Pinus sylvestris saw timber and pulp wood. Scand. J. For. Res. 9:376-381.

Kaitera, J., and Hantula, J. 1998. Melampyrum sylvaticum, a new alternate host for pine stem rust Cronartium flaccidum. Mycologia 90:1028-1030.

Kaitera, J., and Hiltunen, R. 2011. Susceptibility of Pedicularis spp. to Cronartium ribicola and C. flaccidum in Finland. For. Pathol. 41:237-242.

Kaitera, J., and Hiltunen, R. 2012. New alternate hosts for the rusts Cronartium ribicola and Cronartium flaccidum in Finland. Can. J. For. Res.42:1661-1668.

Kaitera, J., Hiltunen, R., and Hantula, J. 2015. Cronartium rust sporulation on hemiparasitic plants. Plant Pathol. 64:738-747.

Kaitera, J., Hiltunen, R., and Hantula, J. 2017a. Nasa, Nemesia and Euphrasia: New alternate hosts of Cronartium spp. For. Pathol. 47:e12306.

Kaitera, J., Hiltunen, R., Kauppila, T., and Hantula, J. 2017b. Five plant families support natural sporulation of Cronartium ribicola and $C$. flaccidum in Finland. Eur. J. Plant Pathol. 149:367-383.

Kaitera, J., Hiltunen, R., and Samils, B. 2012. Alternate host ranges of Cronartium flaccidum and Cronartium ribicola in northern Europe. Botany 90:694-703.

Kaitera, J., Kalleinen, L., Mikkilä, J., and Hantula, J. 2017c. Cronartium flaccidum sporulates on new Euphrasia species in natural habitats in Finland. For. Pathol. 47:e12349.

Kaitera, J., Kauppila, T., and Hantula, J. 2018. New alternate hosts for Cronartium spp.: Odontites, Euphrasia, Rhinanthus and Papaver. For. Pathol. 48:e12466.

Kaitera, J., and Nuorteva, H. 2003a. Cronartium flaccidum produces uredinia and telia on Melampyrum nemorosum and on Finnish Vincetoxicum hirundinaria. For. Pathol. 33:205-213.

Kaitera, J., and Nuorteva, H. 2003b. Relative susceptibility of four Melampyrum species to Cronartium flaccidum. Scand. J. For. Res. 18:499-504.

Kaitera, J., and Nuorteva, H. 2008. Inoculations of eight Pinus species with Cronartium and Peridermium stem rusts. For. Ecol. Manage. 255:973-981.

Kaitera, J., Nuorteva, H., and Hantula, J. 2005. Distribution and frequency of Cronartium flaccidum on Melampyrum spp. in Finland. Can. J. For. Res. 35:229-234.

Kaitera, J., Seitamäki, L., Hantula, J., Jalkanen, R., and Kurkela, T. 1999. Inoculation of known and potential alternate hosts with Peridermium pini and Cronartium flaccidum aeciospores. Mycol. Res. 103:235-241.

Kasanen, R. 1997. Aeciospores of Cronartium flaccidum, C. ribicola and Endocronartium pini show no differences in morphology. Eur. J. For. Pathol. 27:251-260.

Kasanen, R., Kaitera, J., and Hantula, J. 2000. The genetic composition of Peridermium pini and Cronartium flaccidum cankers on Scots pine as revealed by two multi-allelic loci. For. Pathol. 30:221-230.

Kinloch, B. B., Jr. 1972. Genetic variation in resistance to Cronartium and Peridermium rusts in hard pines. Pages 445-463 in: Biology of rust resistance in forest trees: Proceedings NATO-IUFRO Advanced Study Institute August 17-24 1969. R. T. Bingham, R. J. Hoff, and G. I. McDonald, U.S. Department of Agriculture, Forest Service, Washington, DC.

Li, J., Yang, Y. H., Zhou, L., and Cheng, L. J. 2013. Destructive effects of a mycoparasite Trichoderma atroviride SS003 on aeciospores of Cronartium ribicola. J. Phytopathol. 162:396-401.

Lovett, G. M., Canham, C. D., Arthur, M. A., Weathers, K. C., and Fitzhugh, R. D. 2006. Forest ecosystem responses to exotic pests and pathogens in eastern North America. BioScience 56:395-403.

Maloy, O. C. 1997. White pine blister rust control in North America: A case history. Annu. Rev. Phytopathol. 35:87-109.

McDonald, G. I., Hoff, R. J., and Wykoff, W. R. 1981. Computer simulation of white pine blister rust epidemics. I. Model formulation. Research Paper INT-258. U.S. Department 
of Agriculture, Forest Service, Intermountain Forest and Range Experiment Station, Ogden, UT.

Mittempergher, L., and Raddi, P. 1977. Variation of diverse sources of Cronartium flaccidum. Eur. J. For. Pathol. 7:93-98.

Moricca, S., and Ragazzi A. 1996. Culture characteristics and variation of Cronartium flaccidum isolates. Can. J. Bot. 74:924-933.

Moricca, S., and Ragazzi, A. 1998. Use of RFLP and SSCP analysis to differentiate the pine rust Cronartium flaccidum and Peridermium pini. Mycol. Res. 102:666-670.

Murray, J. S. 1964. Establishment of disease susceptibility plantations. Page 4 in: FAO/IUFRO Symposium on Internationally Dangerous Forest Diseases and Insects. 1964 July 20-30. Oxford, UK.

Murray, J. S., Millar, C. S., and van der Kamp, B. J. 1969. Incidence and importance of Peridermium pini (Pers.) Lev. in north-east Scotland. Forestry 42:164-184.

Özkazanç, N. and Maden, S. 2013. Some important shoot and stem fungi in pine (Pinus spp.) and firs (Abies sp.) in western Blacksea region, Turkey. Bartın Orman Fakültesi Dergisi 15:32-38. https://dergipark.org.tr/en/download/article-file/39940.

Pappinen, A., and von Weissenburg, K. 1996. Weevil feeding on Scots pine affects germination of Endocronartium pini. Eur. J. For. Pathol. 26:225-234.

Parker, I. M., and Gilbert, G. S. 2004. The evolutionary ecology of novel plant-pathogen interactions. Annu. Rev. Ecol., Evol. Syst. 35:675-700.

Pei, M. H., and Brodie, J. 1995. Inoculation of young pine seedlings with Peridermium pini from north-east Scotland. Eur. J. For. Pathol. 25:24-30.

Pitt, D. G., Meyer, T., Park, M., MacDonald, L., Buscarini, T., and Thompson, D. G. 2006. Application of slow-release tablets to enhance white pine regeneration: Growth response and efficacy against white pine blister rust. Can. J. For. Res. 36:684-698.

Price, R. A., Liston, A., and Strauss, H. 1998. Phylogeny and systematics of Pinus. Pages 49-63 in: Ecology and Biogeography of Pinus. D. M. Richardson, ed. Cambridge University Press, Cambridge, U.K.

PRISM. 2021. PRISM Gridded Climate Data. Oregon State University, PRISM Climate Group, Corvallis, OR. http://prism.oregonstate.edu.

Raddi, P., and Fagnani, A. 1978. Relative susceptibility to blister rust caused by Cronartium flaccidum of several species of pine. Eur. J. For. Pathol. 8:58-61.

Ragazzi, A. 1983. Development of Cronartium flaccidum (Alb. et Schw.) Wint. on Vincetoxicum officinale Moench in connection with some environmental factors. Phytopathol. Zeitschr. 108:160-171.

Ragazzi, A., and Dellavalle Fedi, I. 1992. Penetration of Cronartium flaccidum into pine needles. Eur. J. For. Pathol. 22:278-283.

Ragazzi, A., Fedi, I. D., and Mesturino, L. 1986. Cronartium flaccidum on Pinus spp.: Relation of inoculum concentration to symptom development. Eur. J. For. Pathol. 16:1621.

Rizzo, D. M., Garbelotto, M., and Hansen, E. M. 2005. Phytophthora ramorum: Integrative research and management of an emerging pathogen in California and Oregon forests. Annu. Rev. Phytopathol. 43:309-335.

Ruefenacht, B., Finco, M. V., Nelson, M. D., Czaplewski, R., Helmer, E. H., Blackard, J. A., Holden, G. R., Lister, A. J., Salajanu, D., Weyermann, D., and Winterberger, K. 2008. Conterminous U.S. and Alaska forest type mapping using forest inventory and analysis data. USDA Forest Service - Forest Inventory and Analysis (FIA) Program \& Geospatial Technology and Applications Center (GTAC), Salt Lake City, UT.

SAFARIS. 2021. Spatial Analytic Framework for Advanced Risk Information Systems (SAFARIS). United States Department of Agriculture and North Carolina State University, Raleigh, NC.

Samils, B., Ihrmark, K., Kaitera, J., Stenlid, J., and Barklund, P. 2011. New genetic markers for identifying Cronartium flaccidum and Peridermium pini and examining genetic variation within and between lesions of Scots pine blister rust in Sweden. Fungal Biol. 115:1303-1311.

Samils, B., Kaitera, J., Persson, T., Stenlid, J., and Barklund, P. 2021. Relationship and genetic structure among autoecious and heteroecious populations of Cronartium pini in northern Fennoscandia. Fungal Ecol. 50:101032.

Species Fungorum. 2021. http://www.speciesfungorum.org/names/Names.asp (accessed June 2020).

U.S. Department of Agriculture, National Agricultural Statistics Service (USDA-NASS). 2019. 2019 Census of Horticultural Specialties. Census of Agriculture. Retrieved 21 May 2021 from https://www.nass.usda.gov/Publications/AgCensus/2017/Online Resources/Census_of_Horticulture_Specialties/index.php.

U.S. EPA. 2003. Generic ecological assessment endpoints (GEAEs) for ecological risk assessment. EPA/630/P02/004F. Risk Assessment Forum. U.S. Environmental Protec- 
tion Agency, Washington, DC. Retrieved 21 May 2021 from https://www.epa.gov/sites/ production/files/2014-11/documents/generic_endpoinsts_2004.pdf.

Van Arsdel, E. P., Riker, A. J., Kouba, T. F., Suomi, V. E., and Bryson, R. A. 1961. The climatic distribution of blister rust on white pine in Wisconsin. Station Paper No. 87. U.S. Department of Agriculture, Forest Service, Lake States Forest Experiment Station, St. Paul, MN.

Vogler, D. R., and Bruns, T. D. 1998. Phylogenetic relationships among the pine stem rust fungi (Cronartium and Peridermium spp.). Mycologia 90:244-257.

Waring, K. M., and O'Hara, K. L. 2005. Silvicultural strategies in forest ecosystem affected by introduced pests. For. Ecol. Manage. 209:27-41.

White, T. J., Bruns, T., Lee, S., and Taylor, J. 1990. Amplification and direct sequencing of fungal ribosomal RNA genes for phylogenetics. Pages 315-322 in: PCR Protocols: A Guide to Methods and Applications. M. A. Innis, D. H. Gelfand, J. J. Sninisky, and T. J. White, eds. Academic Press, San Diego, CA.

Wijesinghe, S. N., McKenzie, E., Wanasinghe, D. N., Boonmee, S., and Jayawardena, R. S. 2019. The genus Cronartium revisited. Plant Pathol. Quar. 9:219-238.

Williams, B. K., Szaro, R. C., and Shapiro, C. D. 2009. Adaptive Management: The U.S. Department of the Interior Technical Guide. Adaptive Management Working Group, U.S. Department of the Interior, Washington, DC. https://www.doi.gov/sites/doi.gov/ files/uploads/TechGuide-WebOptimized-2.pdf.

Yao, J., and Peixin, W. 1991. A study on the blister rust of Pinus massoniana of China. Pages 302-312 in: 3rd IUFRO Rusts of Pine Working Party Conference 1989 September. Banff, AB. Info. Rep. NOR-X-317. Y. Hiratsuka, J. K. Samoil, P. V. Blenis, P. E. Crane, and B. L. Laishley. Canadian Forest Service, Northern Forestry Centre, Edmonton, AB, Canada.

\section{Infrastructure and Experts}

The following individuals have in-depth knowledge and/or experience with Scots pine blister rust:

\section{United States}

Paul Zambino

USDA Forest Service, Forest Health Protection

Coeur d'Alene, ID 83815

208-765-7493,paul.zambino@usda.gov

Bryce A. Richardson

USDA Forest Service, Rocky Mountain Research Station

Moscow, ID 83843

208-883-2322, bryce.richardson2@usda.gov

Ned B. Klopfenstein

USDA Forest Service, Rocky Mountain Research Station

Moscow, ID 83843

208-883-2310, ned.klopfenstein@usda.gov

Jane E. Stewart

Colorado State University, Department of Agricultural Biology

Fort Collins, CO 80525

970-491-8770, Jane.Stewart@colostate.edu

\section{Mee-Sook Kim}

USDA Forest Service, Pacific Northwest Research Station

Corvallis, OR 97331

541-750-7150,meesook.kim@usda.gov

\section{Canada}

Richard Hamelin

University of British Columbia

Vancouver, BC, Canada

604-827-4441, Richard.hamelin@ubc.ca 
Finland

Jarkko Hantula

Natural Resources Institute Finland

Helsinki, Finland

358-29-532-5419, jarkko.hantula@luke.fi

Juha Kaitera

Natural Resources Institute Finland

Oulu, Finland

358-29-532-5553, juha.kaitera@luke.fi

Heikki Nuorteva

Natural Resources Institute Finland

Helsinki, Finland

358-29-532-5459, heikki.nuorteva@luke.fi

\section{Sweden}

Berit Samils

Sveriges lantbruksuniversitet

Uppsala, Sweden

berit.samils@slu.se

\section{Austria}

\section{Thomas Kirisits}

University of Natural Resources and Applied Life Sciences, Institute of

Forest Entomology, Forest Pathology and Forest Protection

Vienna, Austria

43-1-47654-91601, thomas.kirisits@boku.ac.at

\section{Italy}

Salvatore Moricca

Universià degli Studi di Firenze, Scienze e Tecnologie Agrarie, Alimentari,

Ambientali e Forestali

Firenze, Italy

salvatore.moricca@unifi.it

\section{United Kingdom}

\section{Stephen Woodward}

University of Aberdeen, School of Biological Sciences

Aberdeen, Scotland, U.K.

44-1224-272669, s.woodward@abdn.ac.uk

\section{Web Resources}

CABI - Cronartium flaccidum (Scots pine blister rust), https://www.cabi.org/isc/datasheet/16148

Purdue University - The Center for Environmental and Regulatory Information Systems - Cronartium flaccidum (Alb. \& Schwein) Winter, http://download.ceris.purdue.edu/file/3540

British Columbia Ministry of Forests, Forest Practices Code, Pine Stem Rust Management Guidebook - https://www.for.gov.bc.ca/ftp/HFP/ external/!publish/FPC\%20archive/old\%20web\%20site\%20contents/fpc/ fpcguide/PINESTEM/pine-toc.htm

EPPO Global Database - Cronartium flaccidum, https://gd.eppo.int/ taxon/CRONFL 
Plant Parasites of Europe - Cronartium flaccidum (Albertini \& Schweinitz) Winter, 1880, https://bladmineerders.nl/parasites/fungi/basidiomycota/ pucciniomycotina/pucciniales/cronartiaceae/cronartium/cronartium-flaccidum/

Luke - Cronartium flaccidum, Peridermium pini, http://www.metla.fi/ metinfo/metsienterveys/lajit_kansi/crflac-n.htm (Finnish)

USDA APHIS - Plant Import Information, https://www.aphis.usda.gov/ aphis/ourfocus/planthealth/import-information

USDA NIFA - Extension, https://nifa.usda.gov/extension 